University of Nebraska - Lincoln

DigitalCommons@University of Nebraska - Lincoln

\title{
Uptake, Metabolism, and Elimination of Fungicides from Coated Wheat Seeds in Japanese Quail (Coturnix japonica)
}

Michael S. Gross

Thomas G. Bean

Michelle L. Hladik

Barnett A. Rattner

Kathryn M. Kuivila

Follow this and additional works at: https://digitalcommons.unl.edu/usgsstaffpub

Part of the Geology Commons, Oceanography and Atmospheric Sciences and Meteorology Commons, Other Earth Sciences Commons, and the Other Environmental Sciences Commons

This Article is brought to you for free and open access by the US Geological Survey at DigitalCommons@University of Nebraska - Lincoln. It has been accepted for inclusion in USGS Staff -- Published Research by an authorized administrator of DigitalCommons@University of Nebraska - Lincoln. 


\title{
Uptake, Metabolism, and Elimination of Fungicides from Coated Wheat Seeds in Japanese Quail (Coturnix japonica)
}

\author{
Michael S. Gross, ${ }^{*}{ }^{\dagger}$ Thomas G. Bean, ${ }^{\dagger}$ Michelle L. Hladik, Barnett A. Rattner, and Kathryn M. Kuivila
}

Cite This: J. Agric. Food Chem. 2020, 68, 1514-1524

Read Online

ABSTRACT: Pesticides coated to the seed surface potentially pose an ecological risk to granivorous birds that consume incompletely buried or spilled seeds. To assess the toxicokinetics of seeds treated with current-use fungicides, Japanese quail ( Coturnix japonica) were orally dosed with commercially coated wheat seeds. Quail were exposed to metalaxyl, tebuconazole, and fludioxonil at either a low dose $(0.0655,0.0308$, and $0.0328 \mathrm{mg} / \mathrm{kg}$ of body weight, respectively) or a high dose $(0.196,0.0925$, and $0.0985 \mathrm{mg} / \mathrm{kg}$ of body weight, respectively). Fungicides were rapidly absorbed and distributed to tissues. Tebuconazole was metabolized into tert-butylhydroxy-tebuconazole. All compounds were eliminated to below detection limits within $24 \mathrm{~h}$. The high detection frequencies observed in fecal samples potentially offer a non-invasive matrix to monitor pesticide exposure. With the summation of total body burden across plasma, tissue, and fecal samples, less than $9 \%$ of the administered dose was identified as the parent fungicide, demonstrating the importance to monitor both active ingredients and their metabolites in biological samples.

KEYWORDS: metalaxyl, tebuconazole, fludioxonil, fungicides, seed treatment, seed coating

\section{INTRODUCTION}

The direct application of pesticides to a seed surface has experienced rapid growth as an agricultural technique, resulting in increased yields through reduced damage by insects and pathogen-borne diseases. ${ }^{1}$ This growth in seed treatments has coincided with an increased use of neonicotinoid insecticides, with up to $44 \%$ of soybeans, $100 \%$ of corn, and $100 \%$ of wheat in the United States grown from neonicotinoid-treated seeds. ${ }^{2}$ It is also important to note that many seed treatment formulations typically include fungicidal active ingredients in addition to the commonly applied neonicotinoids or are simply a fungicide alone. The abundant use of pesticide-treated seeds poses a potential hazard to granivorous birds that use agricultural farmland as a habitat and food source. The United States Environmental Protection Agency (U.S. EPA) estimated that $100 \%$ of broadcasted seeds, $15 \%$ of sown and lightly covered seeds, and $1 \%$ of drilled seeds remained accessible to granivores. ${ }^{3}$ The number of treated seeds available on the soil surface was affected by the drilling technique, sowing depth, field location, and soil condition. ${ }^{4-6}$ However, pesticidetreated seeds are far more accessible and far more likely to be consumed by (i.e., optimal foraging theory) avian species through concentrated seed spills. In Minnesota, there were an estimated 15000 large spills of pesticide-treated corn, soybean, and wheat seeds during the 2016 planting season alone. ${ }^{7}$ The failure to properly bury seed spills leaves large amounts of treated seeds readily available to birds.

In the U.S., around 50 million acres of wheat are planted annually, making it the third most abundant crop, following corn and soybean. ${ }^{8}$ In 2017, over 500 million acres of wheat were harvested worldwide. ' Nearly 20 species of birds were counted feeding at bait stations that contained untreated wheat seeds and were placed along field edges in the United
Kingdom; these birds ingested 1-392 wheat seeds in a single visit. ${ }^{10}$ The large number of seeds consumed does not necessarily reflect the active ingredient dose that a bird received if the wheat seeds were coated with pesticides. Birds may limit their exposure to pesticides through dehusking, learned aversion, and/or regurgitation. The dehusking of millet, rice, and sunflower seeds removed $15-41 \%$ of the pesticidal active ingredient. ${ }^{11}$ Overall, it has been suggested that the seed-handling behavior of a bird reduced their exposure by $60-85 \% .{ }^{11}$ Furthermore, birds may learn to avoid pesticide-treated seeds following feeding. Red-winged blackbirds (Agelaius phoeniceus) consumed significantly fewer imidacloprid-treated wheat seeds as a result of post-ingestional distress when offered both treated and untreated seeds ad libitum. $^{12}$ Similar results of avoidance were observed for feral pigeons (Columba livia) fed fonofos-treated seeds, and these pigeons further reduced pesticide exposure by approximately $50 \%$ through regurgitation. ${ }^{13}$ The distress caused by the consumption of treated seeds will vary greatly between seed treatment formulations (i.e., active ingredients) and the species of bird.

Numerous birds have been observed consuming pesticidetreated seeds from seed spills. ${ }^{7}$ In France, imidacloprid-coated seeds were implicated as "very likely" and "likely" to have produced mortality in 21 and 49\% of reported incidents, respectively. ${ }^{14}$ Therefore, despite behaviors to limit exposure, lethal effects have been documented in the environment. Birds

Received: September 6, 2019

Revised: January 14, 2020

Accepted: January 24, 2020

Published: January 24, 2020 
that typically dehusk seeds may consume whole seeds when stressors, such as predation or competition (i.e., food and space), are present. ${ }^{10}$ In cases of sensitive species ingesting treated seeds with more toxic active ingredients (e.g., imidacloprid), mortality or sublethal effects could occur before learned aversion or regurgitation. ${ }^{15}$

Recent studies have assessed the fate and toxicity of seedcoating pesticides in birds, with a greater focus on insecticides. $^{16,17,26,18-25}$ Red-legged partridge (Alectoris rufa) dosed with imidacloprid or fipronil insecticides resulted in sublethal effects (e.g., altered plasma biochemistry, oxidative stress, reduced egg fertility, and decreased chick immunity) or increased mortality. ${ }^{16,18,24}$ White-crowned sparrows (Zonotrichia leucophrys) dosed with imidacloprid at environmentally relevant levels failed to return to a northbound orientation following exposure and experienced induced mass loss, reduced feeding, and extended stopover durations. ${ }^{19,26}$ Japanese quail (Coturnix japonica) dosed with imidaclopridtreated wheat seeds at 3 and $9 \%$ of the median lethal dose $\left(\mathrm{LD}_{50}\right)$ exhibited sublethal effects on behavior and physical performance. $^{21}$

In comparison to insecticides, fewer studies have assessed the effects of seed treatment fungicides on avian species. $^{24,25,27-31}$ Difenoconazole, a triazole fungicide, reduced egg length, the number of fertile eggs, and the hatching rate of total eggs in red-legged partridges. ${ }^{24}$ Furthermore, the fungicide thiram affected egg size and reduced clutch size, egg fertility, and brood size in red-legged partridges, with the highest concentrations of thiram producing mortality in $41.6 \%$ of birds. ${ }^{24,27}$ Red-legged partridges dosed with flutriafol had decreased clutch sizes and number of fertile eggs, which resulted in a greater than $50 \%$ reduction in brood size. ${ }^{28}$ Reduced concentrations of thyroid-stimulating hormone (TSH), thyroxine (T4), and triiodothyronine (T3), which may affect reproductive success, were observed in breeding phase red avadavats (Amandava amandava) exposed to mancozeb. ${ }^{25}$ Lastly, male Japanese quail dosed with epoxiconazole experienced a significant decrease in the number of spermatids and a reduction in the number of germ cells visible in testicular canaliculi. ${ }^{29}$

Pesticide-treated seeds are used abundantly in agriculture, and birds are exposed to active ingredients at concentrated doses through ingestion. Previous research has solely focused on the sublethal (i.e., reproductive) or lethal effects of fungicides following laboratory exposures. The documented effects from these studies highlight the importance of understanding the absorption, distribution, metabolism, and excretion of seed treatment pesticides in birds as well as other non-target organisms, to relate tissue concentrations to effects. Using Japanese quail as a model avian species, this is the first study assessing the toxicokinetics of three wheat seed treatment fungicides (metalaxyl, tebuconazole, and fludioxonil).

\section{MATERIALS AND METHODS}

2.1. Chemicals and Materials. Analytical standards of metalaxyl (98.2\%), metalaxyl alanine (95.9\%, CGA-94689), tebuconazole (99\%), tert-butylhydroxy-tebuconazole (99.6\%, HWG-2061, OHTEB), and fludioxonil (99.8\%) were obtained from the U.S. EPA National Pesticide Standard Repository (Fort Meade, MD, U.S.A.). Mass-labeled reference standards of ${ }^{13} \mathrm{C}_{3}$-tebuconazole $(\geq 98.0 \%), d_{3}$ thiamethoxam $(\geq 98.0 \%)$, and $d_{3}$-clothianidin $(\geq 97.0 \%)$ were purchased from Sigma-Aldrich (St. Louis, MO, U.S.A.). $d_{4}$ Imidacloprid (98\%) was acquired from Cambridge Isotope Labo- ratories (Tewksbury, MA, U.S.A.). Untreated and pesticide-treated (Sativa IMF Max) wheat seeds were obtained from the Foundation Seed Project at Kansas State University (Manhattan, KS, U.S.A.). Wheat was treated at a rate of $3.3 \mathrm{~mL}$ of Sativa IMF Max per kilogram of seed using a Gustafson auger type seed treater and a 50:50 (v/v) treatment/water slurry mix.

2.2. Sample Dosing and Collection. Japanese quail used in this study were from a colony raised at the U.S. Geological Survey Patuxent Wildlife Research Center (Laurel, MD, U.S.A.), and procedures were reviewed and approved by an internal Institutional Animal Care and Use Committee (Study 2016-01). To best mimic potential environmental exposure scenarios of granivorous birds to treated seeds in the field, wheat seeds coated with a commercially available seed treatment, Sativa IMF Max (Nufarm Americas, Inc., U.S. EPA registration number 55146-119), were used for dosing. ${ }^{21}$ According to the seed label, Sativa IMF Max wheat seeds contain active ingredients of $11.16 \%$ imidacloprid $(8.6-12.9 \mu \mathrm{g} / \mathrm{seed}), 0.60 \%$ metalaxyl $(0.43-0.66 \mu \mathrm{g} /$ seed $), 0.45 \%$ tebuconazole $(0.33-0.53 \mu \mathrm{g} /$ seed), and $0.36 \%$ fludioxonil $(0.26-0.40 \mu \mathrm{g} / \mathrm{seed}) .^{32}$ The toxicokinetics of the neonicotinoid insecticide, imidacloprid, and its metabolites were the topic of a previous manuscript. ${ }^{21}$

Individual treated wheat seeds were analytically verified (details described below) to contain $0.655 \pm 0.348 \mu \mathrm{g} /$ seed metalaxyl, 0.308 $\pm 0.124 \mu \mathrm{g} /$ seed tebuconazole, $0.328 \pm 0.164 \mu \mathrm{g} /$ seed fludioxonil, and no fungicide metabolites $(n=10$; Figure S1 of the Supporting Information). These measured values are in good agreement with the predicted values calculated from the recommended application rate $\left(2.2-3.3 \mathrm{~mL} / \mathrm{kg}\right.$ of seed) and the average mass of seed $(\sim 33 \mathrm{mg}) .^{32}$ Fungicidal active ingredients were highly variable between individual seeds; relative standard deviations $(n=10)$ of metalaxyl, tebuconazole, and fludioxonil were $53.2,40.3$, and $49.8 \%$, respectively. The individual seed variability is likely the result of the seed treatment application; however, it was reflective of real-world conditions because these seeds were purchased from an applicator that provides treated wheat seeds to growers. Furthermore, this variability was reduced by the multi-seed doses $(n=10$ or 30$)$ administered to quail in this study.

Male birds aged 6-8 weeks were orally gavaged with three gelatin capsules (size 2) each containing 10 wheat seeds for 1 day $(n=43)$ or 10 consecutive days $(n=33)$ in three treatment groups: control $(0$ treated seeds; $n=15)$, low dose (10 treated seeds; $n=30)$, and high dose (30 treated seeds; $n=31$ ). Radiographs estimated the gastrointestinal tract to be full at about 30 wheat seeds; therefore, the low dose represents a bird feeding, and the high dose represents a bird gorging on spilled treated seeds. ${ }^{21}$ Multiple dosing days $(n=10)$ were used to simulate a bird returning to a seed spill to feed and monitor if active ingredients are bioaccumulated or effects were magnified in comparison to a single exposure. The low- and highdosing regimens were equivalent to $0.0655,0.0308$, and $0.0328 \mathrm{mg}$ $\mathrm{kg}^{-1}$ of body weight (bw) day ${ }^{-1}$ and $0.196,0.0928$, and $0.0985 \mathrm{mg}$ $\mathrm{kg}^{-1}$ of bw day ${ }^{-1}$ for metalaxyl, tebuconazole, fludioxonil, respectively. Quail administered a single dose were euthanized at 1,2, 4, and $24 \mathrm{~h}$ post-exposure. Birds dosed for 10 consecutive days were euthanized at 1,4 , and $24 \mathrm{~h}$ post-exposure. The number of control, low-dose, and high-dose birds euthanized at each time point can be found in Table S1 of the Supporting Information. Liver, brain, muscle, kidney, and plasma samples were harvested from each bird. Cloacal droppings of fecal matter, including urates (hereafter "fecal samples"), produced in the $24 \mathrm{~h}$ period following dosing were collected from single-dosed Japanese quail $(n=9)$. Samples were stored at $-20{ }^{\circ} \mathrm{C}$.

2.3. Sample Extraction and Cleanup. All samples were fortified with $d_{4}$-imidacloprid and ${ }^{13} \mathrm{C}_{3}$-tebuconazole as recovery surrogates prior to their extraction.

2.3.1. Seeds. Untreated and treated wheat seeds were extracted via sonication with $10 \mathrm{~mL}$ of methanol for $60 \mathrm{~min}$. A $1 \mathrm{~mL}$ aliquot was removed for the direct analysis of metalaxyl, metalaxyl alanine, tebuconazole, OH-TEB, and fludioxonil.

2.3.2. Plasma. Plasma aliquots of $0.1 \mathrm{~mL}$ were added to $2 \mathrm{~mL}$ centrifuge tubes, and protein precipitated via the addition of $0.3 \mathrm{~mL}$ of acetonitrile. Following centrifugation at $21100 \mathrm{~g}$, the supernatants 


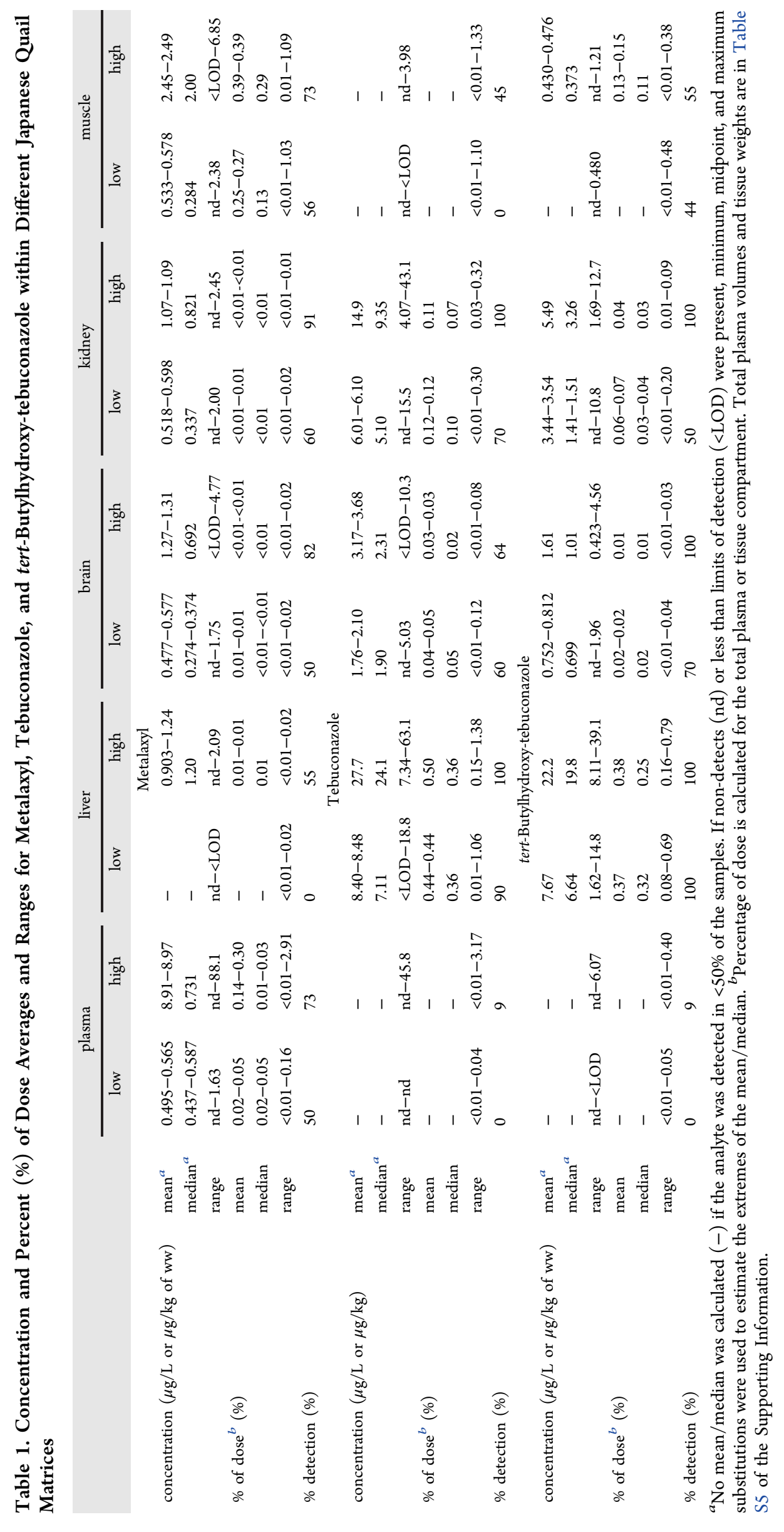



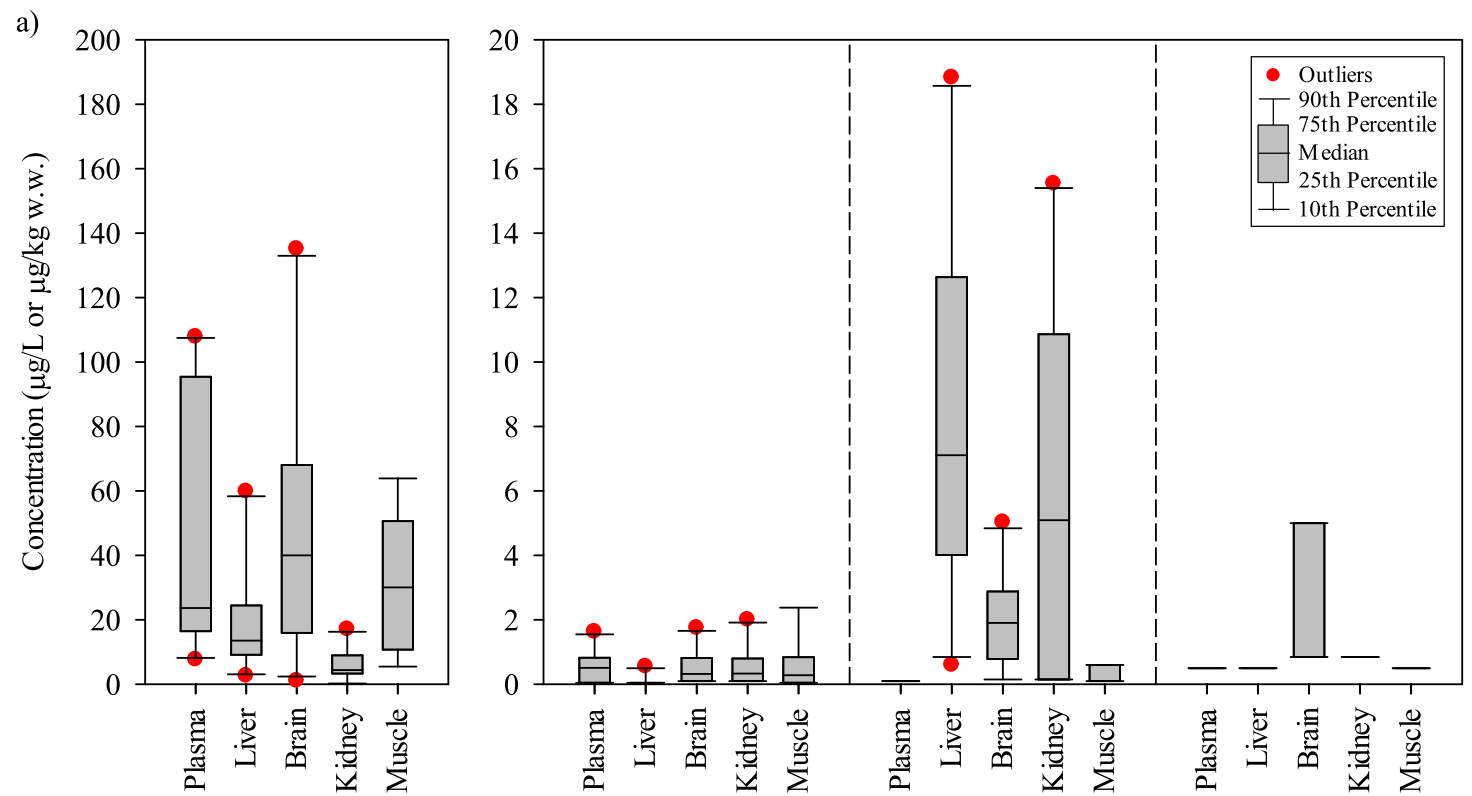

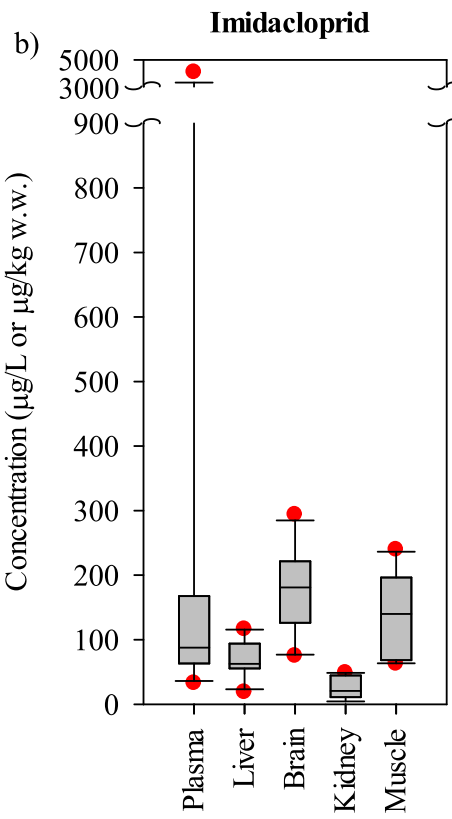

Imidacloprid
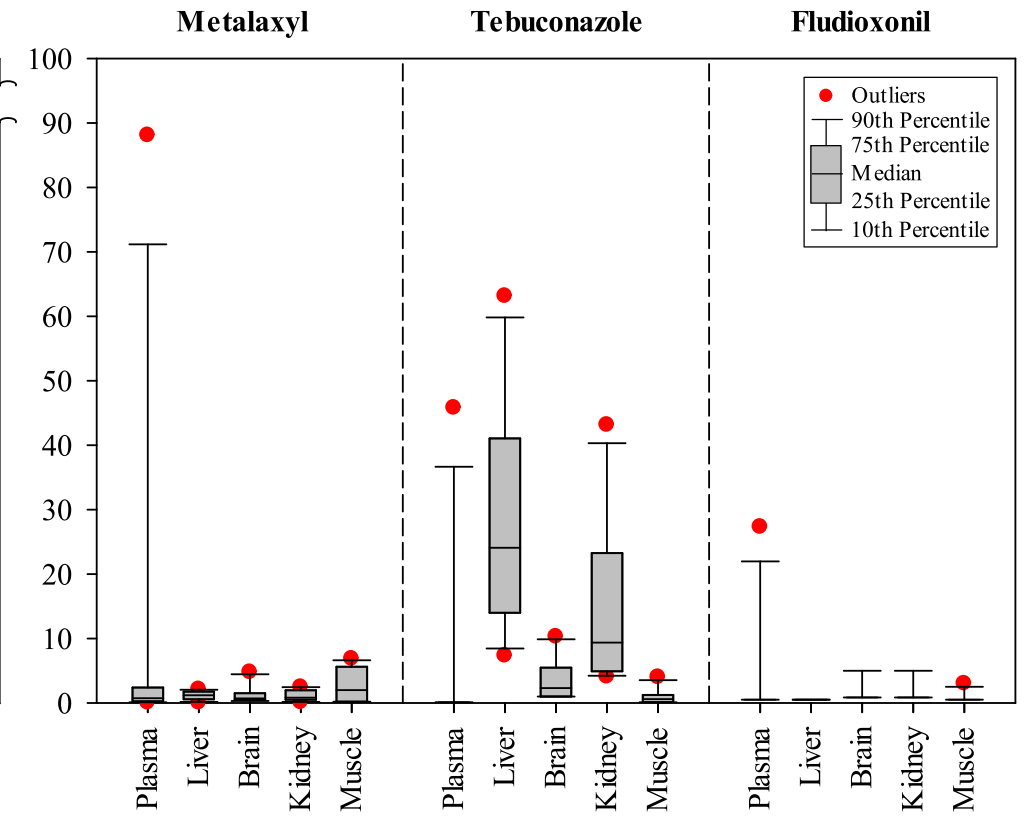

Metalaxyl

Tebuconazole

Fludioxonil

Figure 1. Concentrations of active ingredient fungicides in different Japanese quail tissues compared to imidacloprid. ${ }^{21}$ Graphs represent (a) lowdose $(n=10)$ and $(\mathrm{b})$ high-dose $(n=11)$ birds dosed with treated wheat seeds and euthanized $1 \mathrm{~h}$ post-exposure. The mass $(\mu \mathrm{g} / \mathrm{seed})$ of imidacloprid was approximately $15 \times, 30 \times$, and $30 \times$ the mass of metalaxyl, tebuconazole, and fludioxonil, respectively. Outliers represent data points that lie outside the 10th and 90th percentiles.

were cleaned up via pass-through solid-phase extraction (SPE) using 1 $\mathrm{cm}^{3}, 30 \mathrm{mg}$ Oasis PRiME HLB cartridges. Cartridges were eluted with two $0.25 \mathrm{~mL}$ aliquots of 80:20 (v/v) acetonitrile/water. Final extracts were concentrated to a volume of $0.1 \mathrm{~mL}$.

2.3.3. Tissues. Prior to extraction, tissue samples were weighed and homogenized with sodium sulfate $\left(\mathrm{Na}_{2} \mathrm{SO}_{4}\right)$ using a clean, solventrinsed mortar and pestle. Approximately $0.25 \mathrm{~g}$ of liver and muscle and approximately $0.15 \mathrm{~g}$ of brain and kidney were subsampled for extraction and analysis. Samples were extracted in $33 \mathrm{~mL}$ cells with $50: 50(\mathrm{v} / \mathrm{v})$ acetone/dichloromethane using a Dionex 200 accelerated solvent extraction (ASE) system at $1500 \mathrm{psi}$ and $100{ }^{\circ} \mathrm{C}$ for 3 cycles. Further ASE parameters were as follows: 5 min preheating, $5 \mathrm{~min}$ heating to reach thermal equilibration, 5 min static solvent extraction time, $60 \%$ flush volume, and $120 \mathrm{~s}$ purge time. Extracts were solventexchanged into $1 \mathrm{~mL}$ of acetonitrile for protein precipitation and transferred to $2 \mathrm{~mL}$ centrifuge tubes. Samples were centrifuged at $21100 \mathrm{~g}$, and the supernatants were added to $0.25 \mathrm{~mL}$ of water and passed-through $3 \mathrm{~cm}^{3}, 150 \mathrm{mg}$ Oasis PRiME HLB cartridges. Cartridges were eluted with two $0.25 \mathrm{~mL}$ aliquots of $80: 20(\mathrm{v} / \mathrm{v})$ acetonitrile/water. Tissue extracts were concentrated to a final volume of $0.25 \mathrm{~mL}$.

2.3.4. Fecal Samples. Fecal samples were homogenized using a mortar and pestle, and approximately $0.25 \mathrm{~g}$ was subsampled into a 15 $\mathrm{mL}$ centrifuge tube to be extracted via sonication. Following the addition of $5 \mathrm{~mL}$ of acetonitrile, samples were vortexed for $10 \mathrm{~s}$ and sonicated for $10 \mathrm{~min}$. Fecal samples were centrifuged at $3000 \mathrm{~g}$, and the supernatant was removed. The procedure was repeated, and the supernatants were combined. Samples were cleaned up via passthrough SPE using $3 \mathrm{~cm}^{3}, 150 \mathrm{mg}$ Oasis PRiME HLB cartridges and concentrated to a final volume of $0.25 \mathrm{~mL}$. 
2.3.5. Liquid Chromatography/Tandem Mass Spectrometry (LC) MS/MS) Analysis. Prior to analysis, samples were spiked with an internal standard solution containing $d_{3}$-thiamethoxam and $d_{3}$ clothianidin. Analysis was conducted on an Agilent 1260 bio-inert high-performance liquid chromatograph coupled to an Agilent 6430 Triple Quad LC/MS (Santa Clara, CA, U.S.A.). The system was equipped with a Kinetex EVO $\mathrm{C}_{18}$ column $(2.1 \times 150 \mathrm{~mm}, 2.6 \mu \mathrm{m})$ from Phenomenex (Torrance, CA, U.S.A.). The injection volume was $5 \mu \mathrm{L}$; the flow rate was $0.4 \mathrm{~mL} / \mathrm{min}$; and the column temperature was kept at $30{ }^{\circ} \mathrm{C}$. A gradient elution program between a solution of 5 $\mathrm{mM}$ ammonium formate and $5 \mathrm{mM}$ formic acid (A) and acetonitrile (B) was used for separation. The initial conditions of $95 \% \mathrm{~A}$ and $5 \% \mathrm{~B}$ were held for $2 \mathrm{~min}$ before ramping to $95 \% \mathrm{~B}$ over $6 \mathrm{~min}$. The mobile phase was held at $95 \%$ B for 2 min before being brought back to initial conditions over $0.1 \mathrm{~min}$ and held for $6.9 \mathrm{~min}$ to allow for column reequilibration (17 min total run time). MS was equipped with an electrospray ionization (ESI) source, and analytes were detected using the multiple reaction monitoring (MRM) mode with positive polarity. Table S2 of the Supporting Information gives details of MS parameters and MRM transitions.

2.4. Quality Assurance/Quality Control. Analytes were quantified using matrix-matched calibration curves that spanned $0.25-1000 \mu \mathrm{g} / \mathrm{L}$ and that were prepared from samples collected from unexposed quail. Procedural blanks, matrix spikes, and sample replicates were analyzed concurrently to ensure data integrity. Blank samples did not contain detectable concentrations of analytes. Average recoveries of metalaxyl, metalaxyl alanine, tebuconazole, $\mathrm{OH}-\mathrm{TEB}$, and fludioxonil from matrix spike samples were greater than $70 \%$ in all matrices. The average surrogate recoveries of $d_{4^{-}}$ imidacloprid and ${ }^{13} \mathrm{C}_{3}$-tebuconazole were $86.2 \pm 14.1$ and $83.7 \pm$ $20.8 \%$, respectively. Mean relative percent differences (RPDs) from sample replicates $(n=14)$ were $35.3 \%$ for metalaxyl, $24.4 \%$ for tebuconazole, and $18.4 \%$ for OH-TEB. The RPDs for metalaxyl alanine and fludioxonil could not be calculated because there were no detections within the replicate samples. Instrument limits of detection (iLODs) were calculated using $3 \times$ the standard deviation of eight replicate injections of a standard in solvent (Table S3 of the Supporting Information). Method limits of detection (mLODs) were determined from the lowest standard in the matrix-matched curve that produced a signal-to-noise ratio greater than or equal to 3 (Table S4 of the Supporting Information).

2.5. Data Analysis. As a result of the rapid clearance of fungicides and their metabolites from plasma and tissues, samples often had concentrations less than the mLOD (<LOD) or not detected (nd) altogether. As a result, data analyses (median, mean, range, and halflife estimates) were completed by substituting the minimum, midpoint, and maximum values for $<\mathrm{LOD}$ and nd. The following substitutions were made for <LOD: the minimum value was the iLOD; the midpoint value was the average of the iLOD and mLOD; and the maximum value was the mLOD. The minimum, midpoint, and maximum values substituted for nd were 0 (actually 0.00001 ), the average of 0 and the iLOD, and the iLOD, respectively. Statistical analyses were performed using SigmaPlot 14.0 (Systat Software, Inc., San Jose, CA, U.S.A.) to examine the effect of exposure time ( 1 and 10 days) and dose (low and high) on concentrations of fungicides and metabolites in tissues. A one-way analysis of variance (ANOVA) was performed for each scenario among the different tissues. In scenarios where data were not normally distributed (Shapiro-Wilk normality test), a Kruskal-Wallis one-way ANOVA by ranks was used. Analyte elimination half-lives were estimated assuming first-order kinetics (Supporting Information). Concentrations determined in sample aliquots and the total plasma volume or tissue mass (Table S5 of the Supporting Information) of the entire compartment were used to calculate the percentage of administered dose (i.e., total plasma or tissue burden).

\section{RESULTS AND DISCUSSION}

3.1. Absorption and Distribution of Fungicides. Initial statistical analyses were conducted to elucidate differences of the number of dosing days ( 1 and 10 days) and the dosing concentration (low dose and high dose) on concentrations of metalaxyl and tebuconazole in plasma and tissues. There were no statistically significant differences $(p>0.05)$ in concentrations of metalaxyl and tebuconazole between quail administered a single dose versus those dosed 10 consecutive days for both low- and high-dose samples. This was true for all plasma and tissue samples; however, significant differences were observed for concentrations of metalaxyl $(p<0.001)$ and tebuconazole $(p=0.002)$ in liver and concentrations of metalaxyl in muscle $(p=0.03)$ between low- and high-dose birds (Table S6 of the Supporting Information). Because of the lack of significant differences in concentrations between 1 and 10 day dosing regimens, samples were grouped together by dose (i.e., low dose versus high dose and pooled across the number of days dosed).

Fungicides were rapidly absorbed into plasma and distributed to tissues (liver, brain, kidney, and muscle) following the oral dosing of Japanese quail. Metalaxyl was the only fungicide where concentrations were detected within all sampled matrices. Average plasma concentrations of metalaxyl, tebuconazole, OH-TEB, and fludioxonil in highdose birds were right-skewed by a single bird with concentrations of up to 2 orders of magnitude greater (verified upon reanalysis) than the other samples (Table 1). As a result, median concentrations are reported. Excluding the single outlier, tebuconazole and fludioxonil were not detected in plasma samples. Tebuconazole concentrations, however, were detected within liver, brain, kidney, and muscle, whereas fludioxonil was not detected within any sampled tissue (Figure $1)$.

Concentrations of metalaxyl were detected in $50 \%$ of lowdose and $73 \%$ of high-dose plasma samples at $1 \mathrm{~h}$ postexposure, with median concentrations of $0.437-0.587$ and $0.731 \mu \mathrm{g} / \mathrm{L}$, respectively (Figure 1 and Table 1 ). To calculate the percentage of administered dose for which these concentrations were equivalent, the total plasma volume was estimated by assuming $6-11 \mathrm{~mL}$ of whole blood per $100 \mathrm{~g}$ of body weight, of which $49-55 \%$ is plasma. ${ }^{33,34}$ Because concentrations were rapidly eliminated to below LODs $(<24$ h), the percentage of dose was calculated using only the final dose. As a result, plasma concentrations of metalaxyl ranged from $<0.01$ to $0.16 \%$ of dose for low-dose samples and from $<0.01$ to $2.91 \%$ of dose for high-dose samples (Table 1). Rapid absorption of metalaxyl into the bloodstream is consistent with previous studies in rats (Rattus norvegicus) dosed with the radiolabeled compound, where maximum concentrations of radioactivity occurred at $20 \mathrm{~min}$ in males and $40 \mathrm{~min}$ in females. ${ }^{35}$ Concentrations were reported as metalaxyl equivalents, and therefore, no speciation was completed to determine whether radioactivity was produced by the parent compound or metabolites; thus, no direct comparisons could be made between concentrations or percentage of dose.

Metalaxyl was detected in $50 \%$ of brain, $60 \%$ of kidney, and $56 \%$ of muscle samples from low-dose quail but was not detected in liver. The median concentrations in the low-dose samples were $0.274-0.374,0.337$, and $0.284 \mu \mathrm{g} / \mathrm{kg}$ of wet weight $(\mathrm{ww})$ in brain, kidney, and muscle, respectively (Figure 1a). As a percentage of metalaxyl dosed, concentrations were $<0.01-0.02 \%$ in brain, $<0.01-0.02 \%$ in kidney, and $<0.01-$ $1.03 \%$ in muscle (Table 1). In contrast, metalaxyl was detected in all tissues from high-dose quail ( $55 \%$ of liver, $82 \%$ of brain, $91 \%$ of kidney, and $73 \%$ of muscle samples). Median 

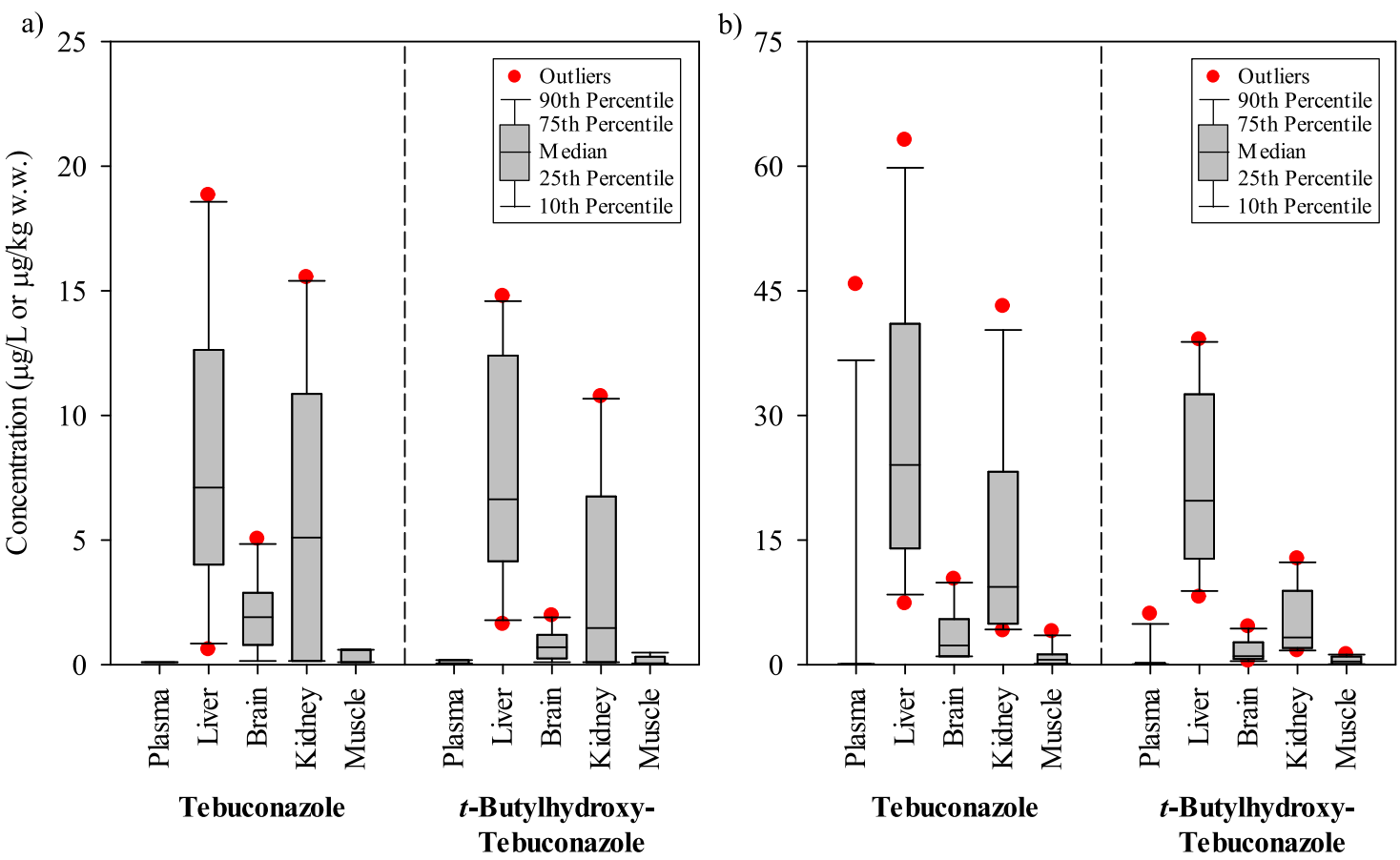

Figure 2. Concentrations of tebuconazole and its metabolite, tert-butylhydroxy-tebuconazole, in tissues of (a) low-dose $(n=10)$ and (b) high-dose $(n=11)$ Japanese quail. Samples represent birds euthanized $1 \mathrm{~h}$ post-exposure. Outliers represent data points that lie outside the 10th and 90th percentiles.

concentrations were $1.20,0.692,0.821$, and $2.00 \mu \mathrm{g} / \mathrm{kg}$ of ww in high-dose liver, brain, kidney, and muscle samples, respectively (Figure $1 \mathrm{~b}$ ). Relating these concentrations to the percentage of metalaxyl dosed showed that high-dose birds had $<0.01-0.02 \%$ in liver, $<0.01-0.02 \%$ in brain, $<0.01-0.01 \%$ in kidney, and $0.01-1.09 \%$ in muscle (Table 1). In chickens ( Gallus gallus) dosed with radiolabeled metalaxyl, concentrations in liver, kidney, thigh muscle, and breast muscle were $0.14,0.04,0.31$, and $0.25 \%$ of the dose. ${ }^{35}$ These results are similar to our study with low levels of metalaxyl detected in plasma and tissues and the highest concentrations in muscle.

Tebuconazole was not detected in any plasma samples at $1 \mathrm{~h}$ post-exposure besides a outlier, a high-dose sample with a concentration of $45.8 \mu \mathrm{g} / \mathrm{L}$. Tebuconazole concentrations were detected in $90 \%$ of liver, $60 \%$ of brain, and $70 \%$ of kidney samples at the low dose but were not detected in muscle. Median concentrations were $7.11,1.90$, and $5.10 \mu \mathrm{g} / \mathrm{kg}$ of ww for low-dose liver, brain, and kidney samples, respectively (Figure 1a). In terms of the percentage of tebuconazole dosed, concentrations ranged from 0.01 to $1.06 \%$ in liver, from $<0.01$ to $0.12 \%$ in brain, and from $<0.01$ to $0.30 \%$ in kidney (Table 1 ). Concentrations were less than the $\mathrm{mLOD}$ for all low-dose muscle samples. In contrast, for high-dose quail, tebuconazole was detected in $100,64,100$, and $45 \%$ of liver, brain, kidney, and muscle samples, respectively. The median tebuconazole concentrations were $24.1 \mu \mathrm{g} / \mathrm{kg}$ of ww in liver, $2.31 \mu \mathrm{g} / \mathrm{kg}$ of $\mathrm{ww}$ in brain, and $9.35 \mu \mathrm{g} / \mathrm{kg}$ of ww in kidney (Figure $1 \mathrm{~b}$ ). No median tebuconazole concentration is reported in muscle because it was detected in less than half of the samples. These concentrations related to the following percentage of dose ranges of $0.15-1.38,<0.01-0.08$, and $0.03-0.32 \%$ in liver, brain, and kidney, respectively (Table 1). Muscle concentrations in high-dose samples ranged from $<0.01$ to $1.33 \%$ of dose. Following the dosing of laying hens with radiolabeled tebuconazole, concentrations of tebuconazole equivalents were the greatest in liver, followed by kidney and muscle, respectively (plasma and brain were not measured). ${ }^{36}$ This pattern was also observed with tebuconazole concentrations from Japanese quail in this study.

Fludioxonil was only detected in one high-dose plasma sample at $27.3 \mu \mathrm{g} / \mathrm{L}$. The failure to detect fludioxonil concentrations within plasma and tissue samples was possibly due to the combination of a lower active ingredient mass coated to the seeds and its higher mLOD. Other possible causes of not detecting fludioxonil in plasma and tissues are unextractable, incorporated residues or rapid elimination. After laying hens were administered radiolabeled fludioxonil, approximately $40 \%$ of fludioxonil equivalents measured by total radioactive residues (TRRs) remained unextractable and/ or associated with biological materials (i.e., proteins) within the tissue pellets. ${ }^{37}$ The exposed hens $\left(10 \mathrm{mg} \mathrm{hen}^{-1} \mathrm{day}^{-1}\right)$ had fludioxonil equivalents detected in plasma, liver, kidney, and muscle. ${ }^{37}$ Following chromatography, fludioxonil accounted for 1.2, 2.6, and 7.9-28\% of the TRRs in liver, kidney, and muscle, respectively. ${ }^{37}$ Fludioxonil was not found to bioaccumulate in tissues, ${ }^{38}$ which was supported by data generated in this study, where fludioxonil was not detected in tissues from birds dosed for 1 or 10 consecutive days.

3.2. Fungicide Metabolism. Registration studies have shown extensive metabolism of fungicidal active ingredients in goats (Capra aegagrus hircus), rats, and hens. ${ }^{35-39}$ These studies identified 14, 10, and 12 metabolites of metalaxyl, tebuconazole, and fludioxonil, respectively. ${ }^{35-37}$ Most metabolites identified in registration studies lacked available analytical standards and, therefore, were not included in the instrumental analysis method. Samples were analyzed for metalaxyl alanine and OH-TEB, two of the more abundant metabolites detected in registration studies. ${ }^{36,39}$ It is beneficial to monitor for potential metabolites of pesticides when assessing exposure of non-target organisms because metabolite 

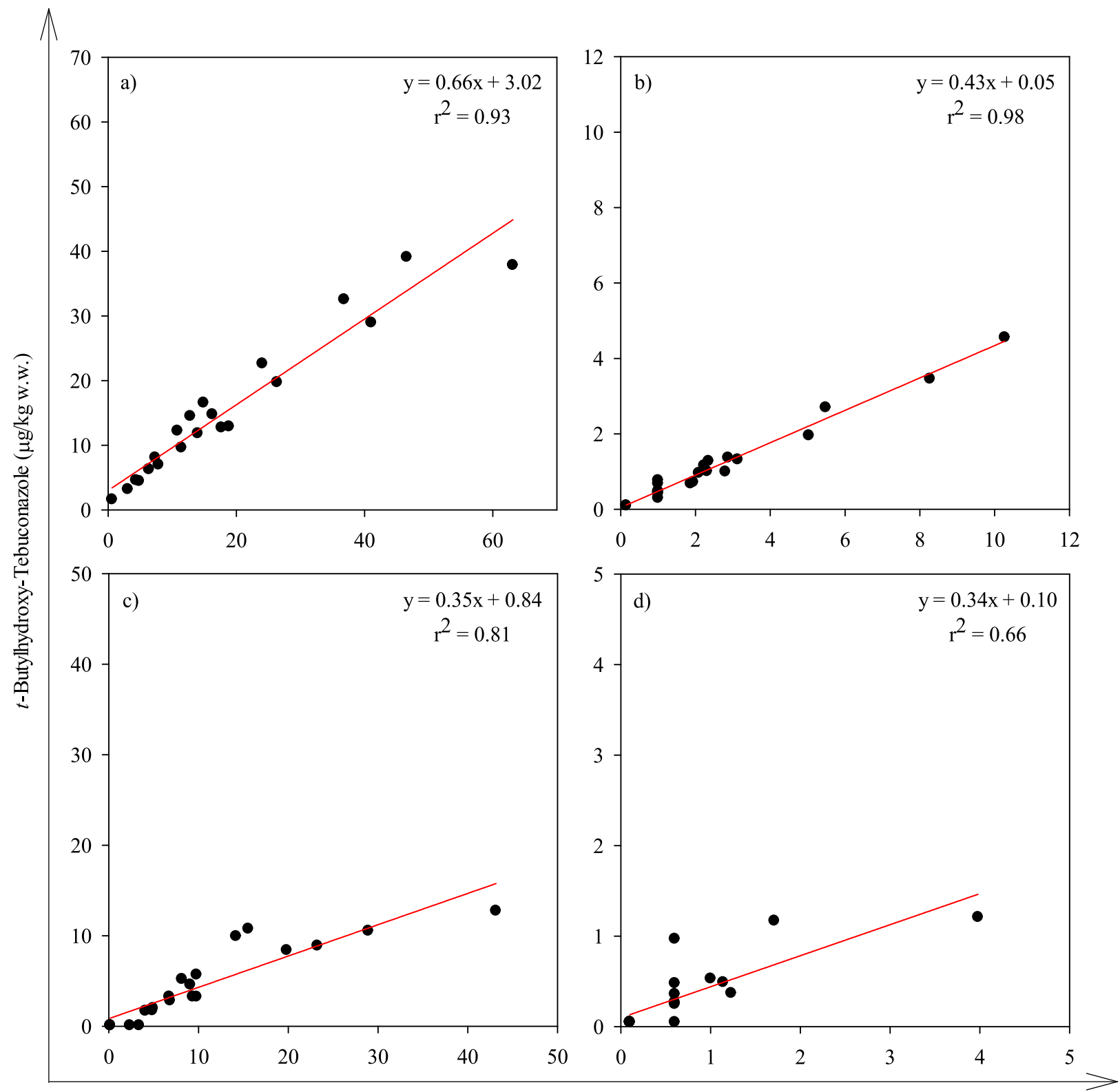

Tebuconazole ( $\mu \mathrm{g} / \mathrm{kg}$ w.w.)

Figure 3. Linear relationship between concentrations of tebuconazole and its hydroxylated metabolite, tert-butylhydroxy-tebuconazole, in (a) liver, (b) brain, (c) kidney, and (d) muscle from low- and high-dose Japanese quail euthanized $1 \mathrm{~h}$ post-exposure $(n=21)$. The linear equation and correlation coefficient are shown in each matrix.

concentrations may exceed the parent compound. For example, average plasma and tissue concentrations of two imidacloprid metabolites, 5-OH-imidacloprid and imidacloprid-olefin, were up to 15 -fold greater than the concentration of imidacloprid following Japanese quail exposure to treated wheat. $^{21}$ The extensive metabolism of fungicidal active ingredients may further explain the low concentrations of parent compounds in plasma and tissues.

Non-detectable levels of metalaxyl alanine in quail plasma and tissues are likely a result of the low dose presented from using a commercially available seed treatment, which also represented a plausible exposure scenario. Metalaxyl alanine had previously been detected at concentrations of $13 \mu \mathrm{g} / \mathrm{kg}$ in liver of chickens dosed for 4 consecutive days with $10 \mathrm{mg} /$ day radiolabeled metalaxyl and that were euthanized $6 \mathrm{~h}$ after the final dose. ${ }^{39}$ This metabolite concentration was similar to the concentration of the parent compound, which was quantified at $18 \mu \mathrm{g} / \mathrm{kg} .{ }^{39}$ Metalaxyl concentrations detected in the liver of Japanese quail were near the mLOD. If quail metabolism of metalaxyl is similar to that of hens, these values suggest that metalaxyl alanine was near or below the $\mathrm{mLOD}$ and likely not formed in appreciable amounts.

In plasma, OH-TEB was only detected $1 \mathrm{~h}$ post-exposure in one high-dose sample at a concentration of $6.07 \mu \mathrm{g} / \mathrm{L}$. In lowdose samples, the hydroxylated metabolite was quantified in $100 \%$ of liver, $70 \%$ of brain, $50 \%$ of kidney, and $44 \%$ of muscle samples. The median concentrations detected in liver, brain, and kidney samples were 6.64, 0.699, and $1.41-1.51 \mu \mathrm{g} / \mathrm{kg}$ of ww, respectively (Figure 2). A median concentration was not reported in muscle because it was detected in less than half of the samples. With the relation of concentrations to the percentage of the parent compound dosed, low-dose 
concentrations of OH-TEB ranged from 0.08 to $0.69 \%$ in liver, from $<0.01$ to $0.04 \%$ in brain, and from $<0.01$ to $0.20 \%$ in kidney (Table 1). Concentrations in muscle ranged from $<0.01$ to $0.48 \%$ of dose. In contrast, the hydroxylated metabolite of tebuconazole was detected in 100,100,100, and 55\% of highdose liver, brain, kidney, and muscle samples, respectively. Median concentrations of OH-TEB were $19.8 \mu \mathrm{g} / \mathrm{kg}$ of ww in liver, $1.01 \mu \mathrm{g} / \mathrm{kg}$ of ww in brain, $3.26 \mu \mathrm{g} / \mathrm{kg}$ of ww in kidney, and $0.373 \mu \mathrm{g} / \mathrm{kg}$ of ww in muscle (Figure 2). Metabolite concentrations as a percentage of tebuconazole dosed were $0.16-0.79 \%$ in liver, $<0.01-0.03 \%$ in brain, $0.01-0.09 \%$ in kidney, and $<0.01-0.38 \%$ in muscle (Table 1 ).

The distribution of the hydroxylated metabolite, OH-TEB, resembled tebuconazole in quail plasma and tissue samples. Concentrations were greatest in the liver, followed by kidney, brain, muscle, and plasma, respectively (Figure 2); however, concentrations of OH-TEB were lower than those of the parent compound. Tebuconazole and OH-TEB concentrations (as a percentage of TRRs) in liver, kidney, and muscle were also similar in chickens dosed with radiolabeled tebuconazole. ${ }^{36}$ Linear regression on paired concentrations of OH-TEB versus tebuconazole in each matrix resulted in slopes of 0.66 , $0.43,0.35$, and 0.34 for liver, brain, kidney, and muscle, respectively. A good correlation was observed among all tissues $\left(r^{2}>0.80\right)$ but was slightly lower in muscle $\left(r^{2}=0.66\right)$ (Figure 3 ). As a result of the low detection frequency in plasma, no correlation was completed.

3.3. Elimination and Excretion of Seed Treatment Fungicides and Metabolites. Seed treatment fungicides and metabolites were rapidly eliminated to below mLODs within $24 \mathrm{~h}$ from all Japanese quail tissues following dosing. Half-life estimates were calculated for metalaxyl, tebuconazole, and $\mathrm{OH}$ TEB using concentrations detected at $1 \mathrm{~h}(n=11), 2 \mathrm{~h}(n=$ $4), 4 \mathrm{~h}(n=8)$, and $24 \mathrm{~h}(n=8)$ from high-dose samples (Figure S2 of the Supporting Information). No half-life estimates were determined for fludioxonil as a result of the low detection frequency. The half-life estimates of metalaxyl ranged from 0.240 to $0.252 \mathrm{~h}$ in plasma, from 0.279 to $1.26 \mathrm{~h}$ in liver, from 0.681 to $1.02 \mathrm{~h}$ in brain, from 0.838 to $1.24 \mathrm{~h}$ in kidney, and from 0.445 to $0.471 \mathrm{~h}$ in muscle (Table 2). These

Table 2. Half-Life (h) Estimates for High-Dose Japanese Quail

$\begin{array}{llcc} & \text { metalaxyl } & \text { tebuconazole } & \text { tert-butylhydroxy-tebuconazole } \\ \text { plasma } & 0.240-0.252 & a & a \\ \text { liver } & 0.279-1.26 & 0.709-0.728 & 0.827-0.836 \\ \text { brain } & 0.681-1.02 & 1.41-1.46 & 1.10-1.37 \\ \text { kidney } & 0.838-1.24 & 0.679-0.679 & 0.782-0.840 \\ \text { muscle } & 0.445-0.471 & a & 0.827-1.25\end{array}$

${ }^{a}$ Half-life was not calculated as a result of the low detection frequency.

half-life estimates were in order with the 0.41 and $0.56 \mathrm{~h}$ halflife estimates for male and female rats, respectively. ${ }^{35}$ As a result of the low number of detections in $1 \mathrm{~h}$ plasma and muscle samples, half-life estimates for tebuconazole and its hydroxylated metabolite were only calculated in liver, brain, and kidney. The half-life estimates of tebuconazole in liver, brain, and kidney ranged from 0.709 to $0.728 \mathrm{~h}$, from 1.41 to $1.46 \mathrm{~h}$, and from 0.679 to $0679 \mathrm{~h}$, respectively (Table 2). For OH-TEB, the half-life estimates ranged from 0.827 to $0.836 \mathrm{~h}$ in liver, from 1.10 to $1.37 \mathrm{~h}$ in brain, from 0.782 to $0.840 \mathrm{~h}$ in kidney, and from 0.827 to $1.25 \mathrm{~h}$ in muscle (Table 2). These values were lower than the total radioactivity half-life of $4.8 \mathrm{~h}$ in plasma following the exposure of chickens to radiolabeled tebuconazole. $^{36}$

Fecal samples collected from birds that received one dose of treated wheat seeds and were euthanized $24 \mathrm{~h}$ post-exposure had detectable concentrations of metalaxyl, tebuconazole, and $\mathrm{OH}-\mathrm{TEB}$ in all low- and high-dose samples. Fludioxonil was not detected in low-dose samples but was detected in 3 of 4 (75\%) high-dose samples. Median concentrations in low-dose samples were $2.03 \mu \mathrm{g} / \mathrm{kg}$ of ww for metalaxyl, $3.59 \mu \mathrm{g} / \mathrm{kg}$ of ww for tebuconazole, and $5.10 \mu \mathrm{g} / \mathrm{kg}$ of ww for OH-TEB (Figure 4). Assuming that Japanese quail produced $9.5 \mathrm{~g}$ of

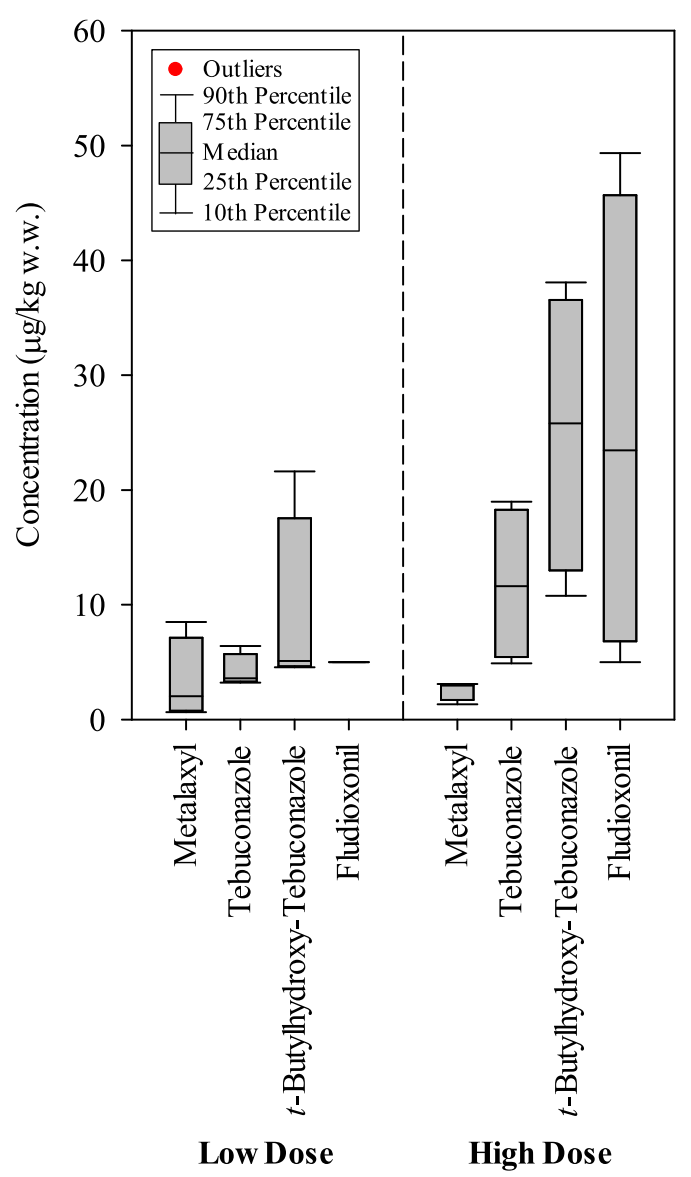

Figure 4. Presence of metalaxyl, tebuconazole, tert-butylhydroxytebuconazole, and fludioxonil in fecal samples collected from Japanese quail euthanized $24 \mathrm{~h}$ post-exposure. Detections were observed for both dosing levels. Outliers represent data points that lie outside the 10th and 90th percentiles.

droppings in $24 \mathrm{~h}$, concentrations as a percentage of parent compound dosed ranged from 0.10 to $1.24 \%$, from 0.98 to $1.96 \%$, and from 1.33 to $6.30 \%$ for metalaxyl, tebuconazole, and $\mathrm{OH}-\mathrm{TEB}$, respectively. Median concentrations in highdose samples were $2.97 \mu \mathrm{g} / \mathrm{kg}$ of ww for metalaxyl, $11.6 \mu \mathrm{g} / \mathrm{kg}$ of ww for tebuconazole, $25.8 \mu \mathrm{g} / \mathrm{kg}$ of ww for OH-TEB, and $23.5 \mu \mathrm{g} / \mathrm{kg}$ of $\mathrm{ww}$ for fludioxonil (Figure 4). Concentrations corresponded to $0.06-0.15,0.50-1.94,1.05-3.70$, and $0.16-$ $4.74 \%$ of active ingredient dosed for metalaxyl, tebuconazole, $\mathrm{OH}-\mathrm{TEB}$, and fludioxonil, respectively.

Following the dosing of hens with radiolabeled fungicides, more than $90 \%$ of metalaxyl, $80 \%$ of tebuconazole, and $102 \%$ of fludioxonil administered doses were detected in excre- 
ta. ${ }^{35-37}$ Because their elimination was only described in terms of TRRs, concentrations or percentage of dose could not be attributed to the parent fungicides or specific metabolites. In our study, tebuconazole was the only fungicide where both the parent compound and a metabolite were quantified. The sum of tebuconazole and OH-TEB concentrations in quail fecal samples ranged from 2.31 to $8.26 \%$ of dose in low-dose samples and $1.55-5.64 \%$ of dose in high-dose samples. Therefore, less than $10 \%$ of the administered dose was identified and quantified in fecal samples for metalaxyl, tebuconazole, and fludioxonil. Our data suggest that most of the fungicide equivalents (TRRs) detected in fecal samples from radiolabeled studies were metabolic products and not the active ingredients. Additional analytical standards of fungicide metabolites or a non-targeted screening approach could potentially identify a greater presence of the administered dose in the fecal samples. Nevertheless, tebuconazole has been detected at concentrations ranging from 50 to $68 \mu \mathrm{g} / \mathrm{kg}$ in fecal matter from red-breasted geese that fed on wheat shoots (with the seed still attached to the root) grown from pesticidetreated seeds. ${ }^{40}$ Monitoring fecal samples for parent pesticides and metabolites may demonstrate recent exposure of nontarget organisms to current-use pesticides. Non-lethal sampling techniques are necessary for monitoring exposure of threatened, endangered, and protected species. In comparison to plasma, fecal samples greatly reduce or eliminate the handling of these species. Furthermore, for tebuconazole and fludioxonil, fecal matter proved to be a better indicator of exposure.

3.4. Fungicide Exposure and Toxicity Hazard in the Environment. Although these fungicides are readily absorbed, metabolized, and excreted, it is important to note they have been detected in tissues and digestive contents of free-ranging wildlife and invertebrates. Frogs collected from wetlands had metalaxyl detections in $19 \%$ of tissue samples, with concentrations ranging up to $269 \mu \mathrm{g} / \mathrm{kg}$ of $\mathrm{ww}$ in livers and up to $382 \mu \mathrm{g} / \mathrm{kg}$ of ww in whole body tissue. ${ }^{41}$ Tebuconazole has been detected in Pacific chorus frogs (Pseudacris regilla) at concentrations up to $363 \mu \mathrm{g} / \mathrm{kg}$ of ww, ${ }^{42}$ native bees at $3.9 \mu \mathrm{g} /$ $\mathrm{kg}^{43}$ and less than $10 \mu \mathrm{g} / \mathrm{kg}$ in gray partridge eggs. ${ }^{44}$ Furthermore, tebuconazole and fludioxonil were two of six fungicides detected in the digestive tract contents of wild partridges. Tebuconazole was detected in $19.1 \%$ of samples, with a maximum concentration of $9.3 \mu \mathrm{g} / \mathrm{g}$, and fludioxonil was detected in $1.0 \%$ of samples, with a maximum concentration of $0.046 \mu \mathrm{g} / \mathrm{g}$. ${ }^{4}$ The detection of fungicides in non-target organisms warrants further studies on their uptake, metabolism, elimination, and toxicity.

In comparison to insecticides, the fungicides used in seed treatments are relatively non-toxic to birds. The median lethal dose $\left(\mathrm{LD}_{50}\right)$ of imidacloprid has been reported as $31 \mathrm{mg} / \mathrm{kg}$ of bw in Japanese quail. ${ }^{17}$ Comparatively, the $\mathrm{LD}_{50}$ values for metalaxyl, tebuconazole, and fludioxonil are $1466 \mathrm{mg} / \mathrm{kg}$ of bw (mallard duck, Anas platyrhynchos), ${ }^{45} 2912 \mathrm{mg} / \mathrm{kg}$ of bw (Japanese quail), ${ }^{46}$ and $>2,000 \mathrm{mg} / \mathrm{kg}$ of bw (bobwhite quail, Colinus virginianus), ${ }^{47}$ respectively, as reported for various avian species. To reach these $\mathrm{LD}_{50}$ values, a $100 \mathrm{~g}$ Japanese quail would have to consume hundreds of seeds for imidacloprid to hundreds of thousands of seeds for the three fungicides. Therefore, it would be unlikely for bird die-offs to occur in the field as a result of consumption of treated seeds containing metalaxyl, tebuconazole, and fludioxonil at the levels tested. Interspecific differences in sensitivity to pesticides may result in adverse effects in different avian species. For instance, the $\mathrm{LD}_{50}$ of imidacloprid alone ranges 19 -fold, from $15 \mathrm{mg} / \mathrm{kg}$ of bw in gray partridge to $283 \mathrm{mg} / \mathrm{kg}$ of bw in mallard duck. ${ }^{17}$ The current study did not demonstrate bioaccumulation of the fungicides in tissues after repeated doses. The behavioral and physical performance effects observed in quail dosed with Sativa IMF Max wheat seeds were attributed to imidacloprid; ${ }^{21}$ however, there was potential for chronic, sublethal (i.e., reproductive), and synergistic effects. Information is currently lacking on the direct and indirect effects of fungicides on vertebrate species. ${ }^{30}$

A search of the Crop Data Management Systems label database obtained 319 products used for wheat in the U.S. that contained fungicidal active ingredients. ${ }^{48}$ This search included products that are used as either seed treatments or sprays. It is important to note that, while metalaxyl, tebuconazole, and fludioxonil were all present at less than $1 \%$ within the Sativa IMF Max formulation, ${ }^{32}$ these fungicides are potentially present at far greater concentrations in other seed treatments used with wheat. For instance, metalaxyl is $30.0 \%(5.12 \mu \mathrm{g} /$ seed) in Acquire; ${ }^{49}$ tebuconazole is $28.3 \%(0.67 \mu \mathrm{g} / \mathrm{seed})$ in Raxil $2.6 \mathrm{~F} ;{ }^{50}$ and fludioxonil is $40.3 \%(0.83-1.65 \mu \mathrm{g} /$ seed $)$ of the products Maxim 4FS and Dyna-Shield Fludioxonil. ${ }^{51,52}$ The active ingredient mass per seed was calculated from the recommended application flow rates reported on the seed labels. Therefore, a granivorous bird consuming wheat seeds coated with an alternative seed treatment formulation could potentially be exposed to up to 8 times the fungicide active ingredient mass received from Sativa IMF Max.

Seed treatment fungicides were rapidly absorbed into the bloodstream and distributed to liver, brain, kidney, and muscle tissues; however, metalaxyl, tebuconazole, and fludioxonil were not found to bioaccumulate within Japanese quail and were rapidly cleared via metabolism and excretion. Across plasma, tissue, and fecal samples, concentrations ranged from $<0.15$ to $2.49 \%$, from $<1.03$ to $4.58 \%$, and from $<1.45$ to $7.76 \%$ of the fungicide dosed for metalaxyl, tebuconazole, and OH-TEB, respectively. The same percentage of parent compound dosed ranges for high-dose samples were $<0.11-4.20 \%$ for metalaxyl, $<0.71-8.22 \%$ for tebuconazole, and $<1.25-5.39 \%$ for $\mathrm{OH}$ TEB. Summing tebuconazole and OH-TEB in both low- and high-dose samples resulted in less than $15 \%$ of the tebuconazole dosed being identified. It was hypothesized that the parent fungicides either remained in the digestive contents of Japanese quail or were biotransformed into metabolites that lacked analytical standards. The high detection frequencies of fungicides and metabolites in fecal samples potentially offer a non-invasive, non-lethal sampling technique to monitor recent avian exposure to current-use pesticides in the environment. It is critical to monitor biological samples for metabolic products because less than $9 \%$ of the administered dose was identified as the parent compound. Application of high-resolution, accurate mass (HRAM) mass spectrometry or synthesis of new analytical standards could better characterize the fate of fungicides in quail plasma, tissue, and fecal samples. As a result of interspecific differences in sensitivity and the immense number of synthetic pesticides with varying physicochemical properties used in seed coatings, it is important to continue assessing the toxicokinetics of seed treatment pesticides in non-target organisms. 


\section{ASSOCIATED CONTENT}

\section{SI Supporting Information}

The Supporting Information is available free of charge at https://pubs.acs.org/doi/10.1021/acs.jafc.9b05668.

Additional text describing the half-life calculation, active ingredient masses per seed (Figure S1), elimination graphs (Figure S2), experimental dosing setup and time euthanized post-exposure (Table S1), mass spectrometer parameters (Table S2), instrument limits of detection (Table S3), method limits of detection (Table S4), plasma volume estimates and tissue weights (Table S5), and statistical values (Table S6) (PDF)

\section{AUTHOR INFORMATION}

\section{Corresponding Author}

Michael S. Gross - California Water Science Center, United States Geological Survey, Sacramento, California 95819, United States; (1) orcid.org/0000-0002-2433-166X;

Email: msgross@usgs.gov

\section{Authors}

Thomas G. Bean - Department of Environmental Science and Technology, University of Maryland, College Park, Maryland 20742, United States

Michelle L. Hladik - California Water Science Center, United States Geological Survey, Sacramento, California 95819, United States; Corcid.org/0000-0002-0891-2712

Barnett A. Rattner - Patuxent Wildlife Research Center, United States Geological Survey, Beltsville, Maryland 20705, United States; 이이. orcid.org/0000-0003-3676-2843

Kathryn M. Kuivila - Oregon Water Science Center, United States Geological Survey, Portland, Oregon 97201, United States

Complete contact information is available at:

https://pubs.acs.org/10.1021/acs.jafc.9b05668

\section{Author Contributions \\ ${ }^{\dagger}$ Michael S. Gross and Thomas G. Bean contributed equally to this work.}

\section{Funding}

This work was supported by the United States Geological Survey Toxic Substances Hydrology Program and Contaminant Biology Program in the Environmental Health mission area. Any use of trade, firm, or product names is for descriptive purposes only and does not imply endorsement by the U.S. Government. All of the data described in this manuscript is publicly available: Gross, M. S.; Hladik, M. L.; Kuivila, K. M. Absorption, Distribution, Metabolism, and Elimination of SeedTreatment Pesticides Following the Dosing of Japanese Quail (Coturnix japonica); United States Geological Survey (USGS): Reston, VA, 2019; USGS Data Release, 10.5066/P95PYAEY.

\section{Notes}

The authors declare no competing financial interest.

\section{ACKNOWLEDGMENTS}

The authors acknowledge Natalie K. Karouna-Renier, Paula F. Henry, and Sandra L. Schultz for their help and insight throughout this study.

\section{REFERENCES}

(1) CropLife Foundation (CLF). The Role of Seed Treatment in Modern US Crop Production: A Review of Benefits; CLF: Washington, D.C., 2013.

(2) Douglas, M. R.; Tooker, J. F. Large-Scale Deployment of Seed Treatments Has Driven Rapid Increase in Use of Neonicotinoid Insecticides and Preemptive Pest Management in U.S. Field Crops. Environ. Sci. Technol. 2015, 49 (8), 5088-5097.

(3) United States Environmental Protection Agency (U.S. EPA). Refinements for Risk Assessment of Pesticide Treated Seeds-Interim Guidance; U.S. EPA: Washington, D.C., 2016.

(4) Lopez-Antia, A.; Feliu, J.; Camarero, P. R.; Ortiz-Santaliestra, M. E.; Mateo, R. Risk Assessment of Pesticide Seed Treatment for Farmland Birds Using Refined Field Data. J. Appl. Ecol. 2016, 53, 1373-1381.

(5) de Snoo, G. R.; Luttik, R. Availability of Pesticide-Treated Seed on Arable Fields. Pest Manage. Sci. 2004, 60 (5), 501-506.

(6) Pascual, J. A.; Hart, A. D. M.; Saunders, P. J.; McKay, H. V.; Kilpatrick, J.; Prosser, P. Agricultural Methods to Reduce the Risk to Birds from Cereal Seed Treatments on Fenlands in Eastern England. I. Sowing Depth Manipulation. Agric., Ecosyst. Environ. 1999, 72 (1), 59-73.

(7) Roy, C. L.; Coy, P. L.; Chen, D.; Ponder, J.; Jankowski, M. Multi-Scale Availability of Neonicotinoid-Treated Seed for Wildlife in an Agricultural Landscape during Spring Planting. Sci. Total Environ. 2019, 682, 271-281.

(8) Economic Research Service (ERS), United States Department of Agriculture (USDA). Wheat: Overview; https://www.ers.usda.gov/ topics/crops/wheat/ (accessed May 22, 2019).

(9) Food and Agriculture Organization of the United Nations (FAO). FAOSTAT: Production-Crops; http://www.fao.org/faostat/ en/\#data/QC (accessed Nov 21, 2019).

(10) Prosser, P.; Hart, A. D. M. Assessing Potential Exposure of Birds to Pesticide-Treated Seeds. Ecotoxicology 2005, 14 (7), 679691.

(11) Avery, M. L.; Fischer, D. L.; Primus, T. M. Assessing the Hazard to Granivorous Birds Feeding on Chemically Treated Seeds. Pestic. Sci. 1997, 49, 362-366.

(12) Avery, M. L.; Decker, D. G.; Fischer, D. L.; Stafford, T. R. Responses of Captive Blackbirds to a New Insecticidal Seed Treatment. J. Wildl. Manage. 1993, 57 (3), 652-656.

(13) Pascual, J. A.; Hart, A. D. M.; Fryday, S. L. Incidence of Lethal Bird Poisoning Reduced by Regurgitation of Pesticide-Treated Food. Environ. Toxicol. Chem. 1999, 18 (2), 247-253.

(14) Millot, F.; Decors, A.; Mastain, O.; Quintaine, T.; Berny, P.; Vey, D.; Lasseur, R.; Bro, E. Field Evidence of Bird Poisonings by Imidacloprid-Treated Seeds: A Review of Incidents Reported by the French SAGIR Network from 1995 to 2014. Environ. Sci. Pollut. Res. 2017, 24, 5469-5485.

(15) Lopez-Antia, A.; Ortiz-Santaliestra, M. E.; Mateo, R. Experimental Approaches to Test Pesticide-Treated Seed Avoidance by Birds under a Simulated Diversification of Food Sources. Sci. Total Environ. 2014, 496, 179-187.

(16) Lopez-Antia, A.; Ortiz-Santaliestra, M. E.; Mougeot, F.; Mateo, R. Imidacloprid-Treated Seed Ingestion Has Lethal Effect on Adult Partridges and Reduces Both Breeding Investment and Offspring Immunity. Environ. Res. 2015, 136, 97-107.

(17) Mineau, P.; Palmer, C. The Impact of the Nation's Most Widely Used Insecticides on Birds; American Bird Conservancy: The Plains, VA, 2013.

(18) Lopez-Antia, A.; Ortiz-Santaliestra, M. E.; Camarero, P. R.; Mougeot, F.; Mateo, R. Assessing the Risk of Fipronil-Treated Seed Ingestion and Associated Adverse Effects in the Red-Legged Partridge. Environ. Sci. Technol. 2015, 49 (22), 13649-13657.

(19) Eng, M. L.; Stutchbury, B. J. M.; Morrissey, C. A. Imidacloprid and Chlorpyrifos Insecticides Impair Migratory Ability in a SeedEating Songbird. Sci. Rep. 2017, 7, 15176.

(20) Gobeli, A.; Crossley, D., II; Johnson, J.; Reyna, K. The Effects of Neonicotinoid Exposure on Embryonic Development and Organ 
Mass in Northern Bobwhite Quail (Colinus virginianus). Comp. Biochem. Physiol., Part C: Toxicol. Pharmacol. 2017, 195, 9-15.

(21) Bean, T. G.; Gross, M. S.; Karouna-Renier, N. K.; Henry, P. F. P.; Schultz, S. L.; Hladik, M. L.; Kuivila, K. M.; Rattner, B. A. Toxicokinetics of Imidacloprid-Coated Wheat Seeds in Japanese Quail (Coturnix japonica) and an Evaluation of Hazard. Environ. Sci. Technol. 2019, 53, 3888-3897.

(22) Addy-Orduna, L. M.; Brodeur, J. C.; Mateo, R. Oral Acute Toxicity of Imidacloprid, Thiamethoxam and Clothianidin in Eared Doves: A Contribution for the Risk Assessment of Neonicotinoids in Birds. Sci. Total Environ. 2019, 650, 1216-1223.

(23) Abu Zeid, E. H.; Alam, R. T. M.; Ali, S. A.; Hendawi, M. Y. Dose-Related Impacts of Imidacloprid Oral Intoxication on Brain and Liver of Rock Pigeon (Columba Livia Domestica), Residues Analysis in Different Organs. Ecotoxicol. Environ. Saf. 2019, 167, 60-68.

(24) Lopez-Antia, A.; Ortiz-Santaliestra, M. E.; Mougeot, F.; Mateo, R. Experimental Exposure of Red-Legged Partridges (Alectoris Rufa) to Seeds Coated with Imidacloprid, Thiram and Difenoconazole. Ecotoxicology 2013, 22, 125-138.

(25) Pandey, S. P.; Mohanty, B. The Neonicotinoid Pesticide Imidacloprid and the Dithiocarbamate Fungicide Mancozeb Disrupt the Pituitary-Thyroid Axis of a Wildlife Bird. Chemosphere 2015, 122, 227-234.

(26) Eng, M. L.; Stutchbury, B. J. M.; Morrissey, C. A. A Neonicotinoid Insecticide Reduces Fueling and Delays Migration in Songbirds. Science 2019, 365, 1177-1180.

(27) Lopez-Antia, A.; Ortiz-Santaliestra, M. E.; Blas, E. G.-D.; Camarero, P. R.; Mougeot, F.; Mateo, R. Adverse Effects of ThiramTreated Seed Ingestion on the Reproductive Performance and the Offspring Immune Function of the Red-Legged Partridge. Environ. Toxicol. Chem. 2015, 34 (6), 1320-1329.

(28) Lopez-Antia, A.; Ortiz-Santaliestra, M. E.; Mougeot, F.; Camarero, P. R.; Mateo, R. Brood Size Is Reduced by Half in Birds Feeding on Flutriafol-Treated Seeds below the Recommended Application Rate. Environ. Pollut. 2018, 243, 418-426.

(29) Grote, K.; Niemann, L.; Selzsam, B.; Haider, W.; Gericke, C.; Herzler, M.; Chahoud, I. Epoxiconazole Causes Changes in Testicular Histology and Sperm Production in the Japanese Quail (Coturnix coturnix japonica). Environ. Toxicol. Chem. 2008, 27 (11), 2368-2374.

(30) Zubrod, J. P.; Bundschuh, M.; Arts, G.; Brühl, C.; Imfeld, G.; Knäbel, A.; Payraudeau, S.; Rasmussen, J. J.; Rohr, J.; Scharmüller, A.; Smalling, K.; Stehle, S.; Schulz, R.; Schäfer, R. B. Fungicides: An Overlooked Pesticide Class? Environ. Sci. Technol. 2019, 53 (7), $3347-3365$.

(31) Köhler, H. R.; Triebskorn, R. Wildlife Ecotoxicology of Pesticides: Can We Track Effects to the Population Level and Beyond? Science 2013, 341 (6147), 759-765.

(32) Nufarm Americas. Sativa ${ }^{\circledR}$ IMF Max Seed Treatment; http:// www.cdms.net/ldat/ldB6M002.pdf (accessed June 5, 2019).

(33) Sturkie, P. D. Avian Physiology; Springer: New York, 2012.

(34) Pravda, D.; Boda, K.; Baumgartner, J.; Jelinek, P.; Kucinsky, P.; Okruhlica, M.; Petrovska, E. Haematological Parameters of Japanese Quail (Coturnix coturnix japonica) Kept in Cages under Normal Conditions and Exposed to Long-Time Experimental Hypodynamy. Acta Vet. Brun. 1996, 65, 93-97.

(35) Food and Agriculture Organization of the United Nations (FAO) and World Health Organization (WHO). Joint FAO/WHO Meeting on Pesticide Residues (JMPR): Pesticide Evaluation Metalaxyl and Metalaxyl-M; FAO and WHO: Rome, Italy, 2002.

(36) Food and Agriculture Organization of the United Nations (FAO) and World Health Organization (WHO). Joint FAO/WHO Meeting on Pesticide Residues (JMPR): Pesticide Evaluation Tebuconazole (188); FAO and WHO: Rome, Italy, 1994.

(37) Food and Agriculture Organization of the United Nations (FAO) and World Health Organization (WHO). Joint FAO/WHO Meeting on Pesticide Residues (JMPR): Pesticide Evaluation Fludioxonil (211); FAO and WHO: Rome, Italy, 2004.
(38) European Food Safety Authority (EFSA). Conclusion Regarding the Peer Review of the Pesticide Risk Assessment of the Active Substance Fludioxonil; EFSA: Parma, Italy, 2007.

(39) Food and Agriculture Organization of the United Nations (FAO) and World Health Organization (WHO). Joint FAO/WHO Meeting on Pesticide Residues (JMPR): Pesticide Evaluation Metalaxyl-M (212); FAO and WHO: Rome, Italy, 2004.

(40) Mateo, R.; Petkov, N.; Lopez-Antia, A.; Rodríguez-Estival, J.; Green, A. J. Risk Assessment of Lead Poisoning and Pesticide Exposure in the Declining Population of Red-Breasted Goose (Branta Ruficollis) Wintering in Eastern Europe. Environ. Res. 2016, 151, 359-367.

(41) Smalling, K. L.; Reeves, R.; Muths, E.; Vandever, M.; Battaglin, W. A.; Hladik, M. L.; Pierce, C. L. Pesticide Concentrations in Frog Tissue and Wetland Habitats in a Landscape Dominated by Agriculture. Sci. Total Environ. 2015, 502, 80-90.

(42) Smalling, K. L.; Fellers, G. M.; Kleeman, P. M.; Kuivila, K. M. Accumulation of Pesticides in Pacific Chorus Frogs (Pseudacris Regilla) from California's Sierra Nevada Mountains, USA. Environ. Toxicol. Chem. 2013, 32 (9), 2026-2034.

(43) Hladik, M. L.; Vandever, M.; Smalling, K. L. Exposure of Native Bees Foraging in an Agricultural Landscape to Current-Use Pesticides. Sci. Total Environ. 2016, 542, 469-477.

(44) Bro, E.; Devillers, J.; Millot, F.; Decors, A. Residues of Plant Protection Products in Grey Partridge Eggs in French Cereal Ecosystems. Environ. Sci. Pollut. Res. 2016, 23 (10), 9559-9573.

(45) United States Environmental Protection Agency (U.S. EPA). Reregistration Eligibility Decision (RED) Metalaxyl; U.S. EPA: Washington, D.C., 1994; EPA 738-R-94-017.

(46) Bayer CropScience. Safety Data Sheet-Hombre® Ultra Cereal Seed Treatment; https://www.crop.bayer.com.au/find-crop-solutions/ by-product/bayer-seedgrowth/hombre-ultra-cereal-seedtreatment\#tab-3 (accessed June 5, 2019).

(47) Syngenta Crop Protection. Safety Data Sheet-CRUISERMAXX®; http://www.cdms.net/ldat/mp7JC006.pdf (accessed June 5, 2019).

(48) Crop Data Management Systems, Inc. Label Database; http:// www.cdms.net/Label-Database (accessed June 5, 2019).

(49) BASF Corporation. Acquire ${ }^{\circledR}$ Fungicide Seed Treatment; http:// www.cdms.net/ldat/ld4SC002.pdf (accessed June 5, 2019).

(50) Bayer CropScience. Raxil ${ }^{\circledR}$ 2.6F Seed Treatment Fungicide; http://www.cdms.net/ldat/ld9NJ005.pdf (accessed June 5, 2019).

(51) Syngenta Crop Protection. Maxim ${ }^{\circledR}$ 4FS Fungicide; http:// www.cdms.net/ldat/ld0FU000.pdf (accessed June 5, 2019).

(52) Loveland Products. DynaShield® Fludioxonil; http://www. cdms.net/ldat/ldB9S003.pdf (accessed June 5, 2019). 


\section{SUPPORTING INFORMATION}

Uptake and metabolism of fungicides from coated wheat seeds in dosed Japanese quail (Coturnix japonica)

Michael S. Gross ${ }^{1}$, Thomas G. Bean ${ }^{2}$, Michelle L. Hladik ${ }^{1}$, Barnett A. Rattner ${ }^{3}$, Kathryn M. Kuivila ${ }^{4}$

${ }^{1}$ U.S. Geological Survey, California Water Science Center, Sacramento, CA 95819

${ }^{2}$ Department of Environmental Science and Technology, University of Maryland, College Park, MD 20742

${ }^{3}$ U.S. Geological Survey, Patuxent Wildlife Research Center, Beltsville, MD 20705

${ }^{4}$ U.S. Geological Survey, Oregon Water Science Center, Portland, OR 97201

Number of figures: 2

Number of tables: 6

Number of pages: 14 


\section{Half-life Calculation:}

Half-lives were estimated assuming first order kinetics. Metalaxyl, tebuconazole, and $t$ butylhydroxy-tebuconazole concentrations were plotted over time (1, 2, 4, and $24 \mathrm{~h})$. Data were fit to the following equation:

$$
C=C_{0} e^{-k t}
$$

where $C$ is the concentration, $C_{0}$ is the y-axis intercept, $k$ is the elimination rate constant, and $t$ is time. Half-lives were estimated by dividing the $\ln (2)$ by the rate constant $(k)$. Plots are seen in Figure S2. 

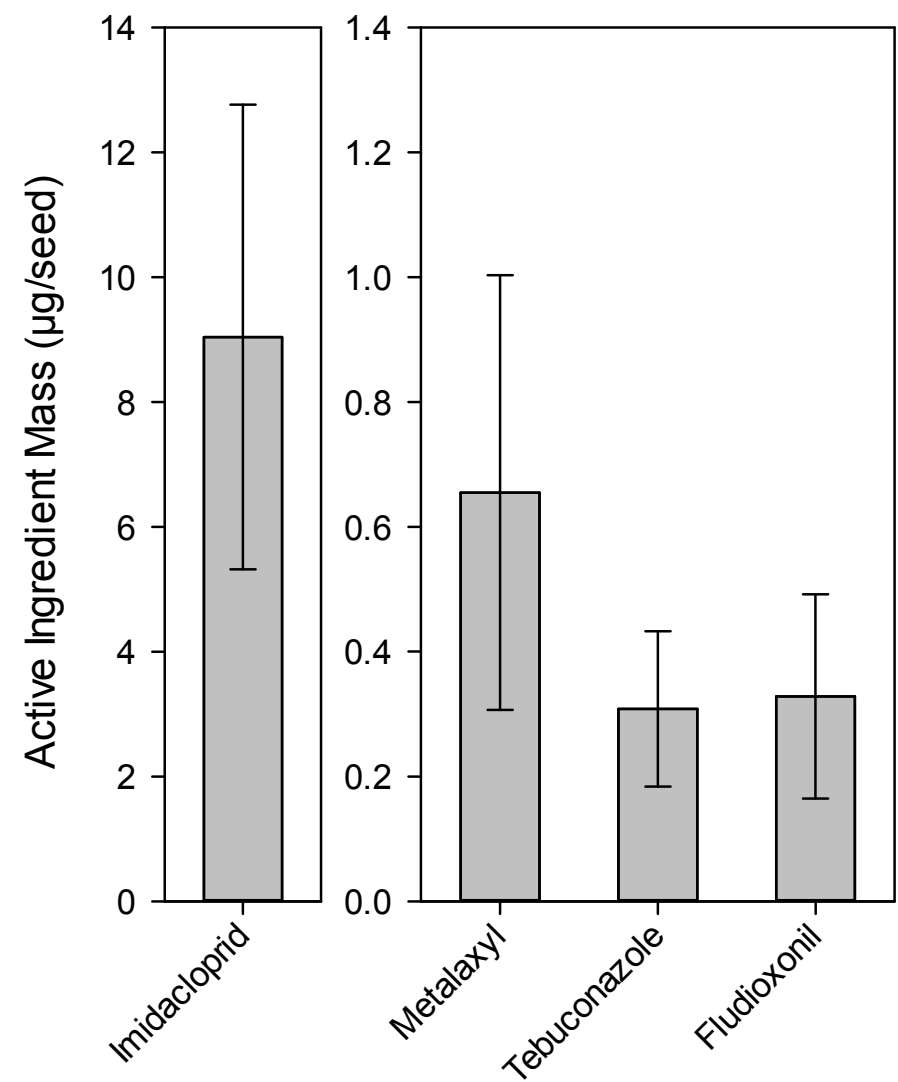

Figure S1: Mean \pm standard deviation $(n=10)$ of active ingredients masses $(\mu \mathrm{g} / \mathrm{seed})$ from Sativa ${ }^{\circledR}$ IMF Max treated wheat seeds. 


\section{$\underline{\text { Metalaxyl, Plasma }}$}

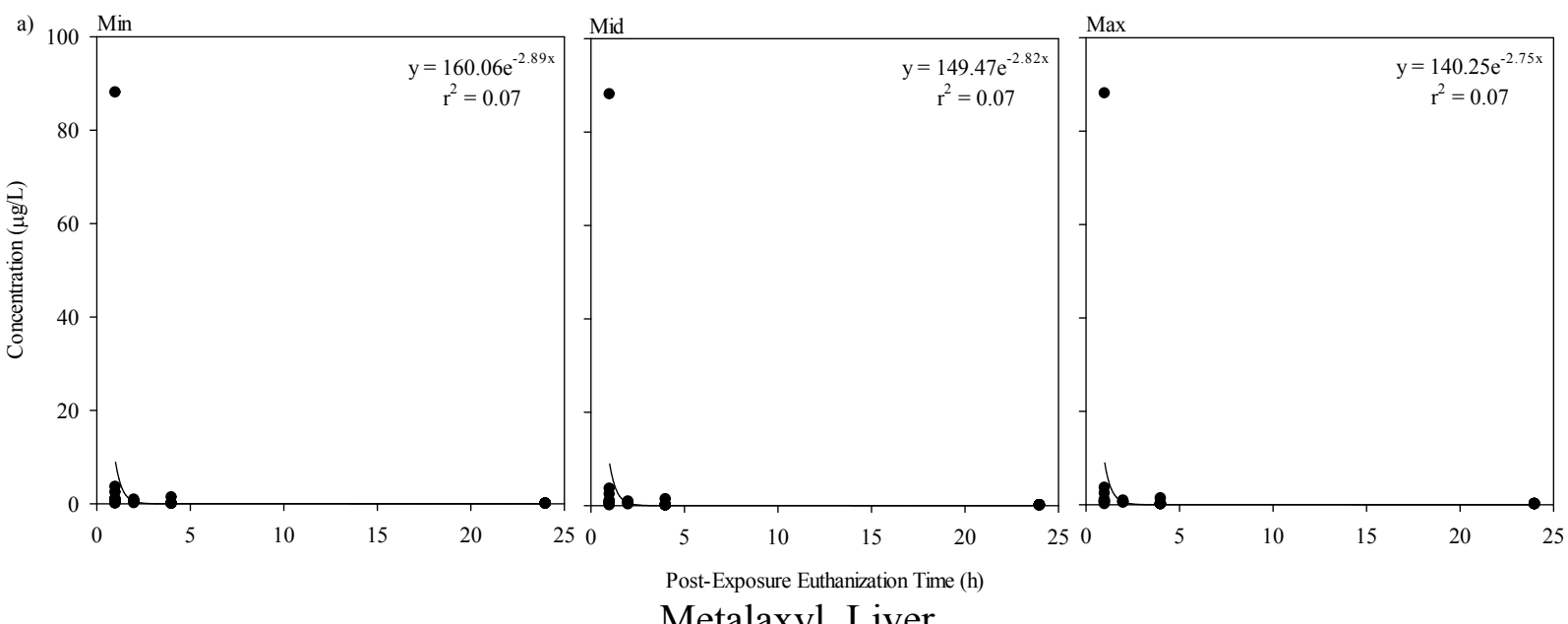

Metalaxyl, Liver
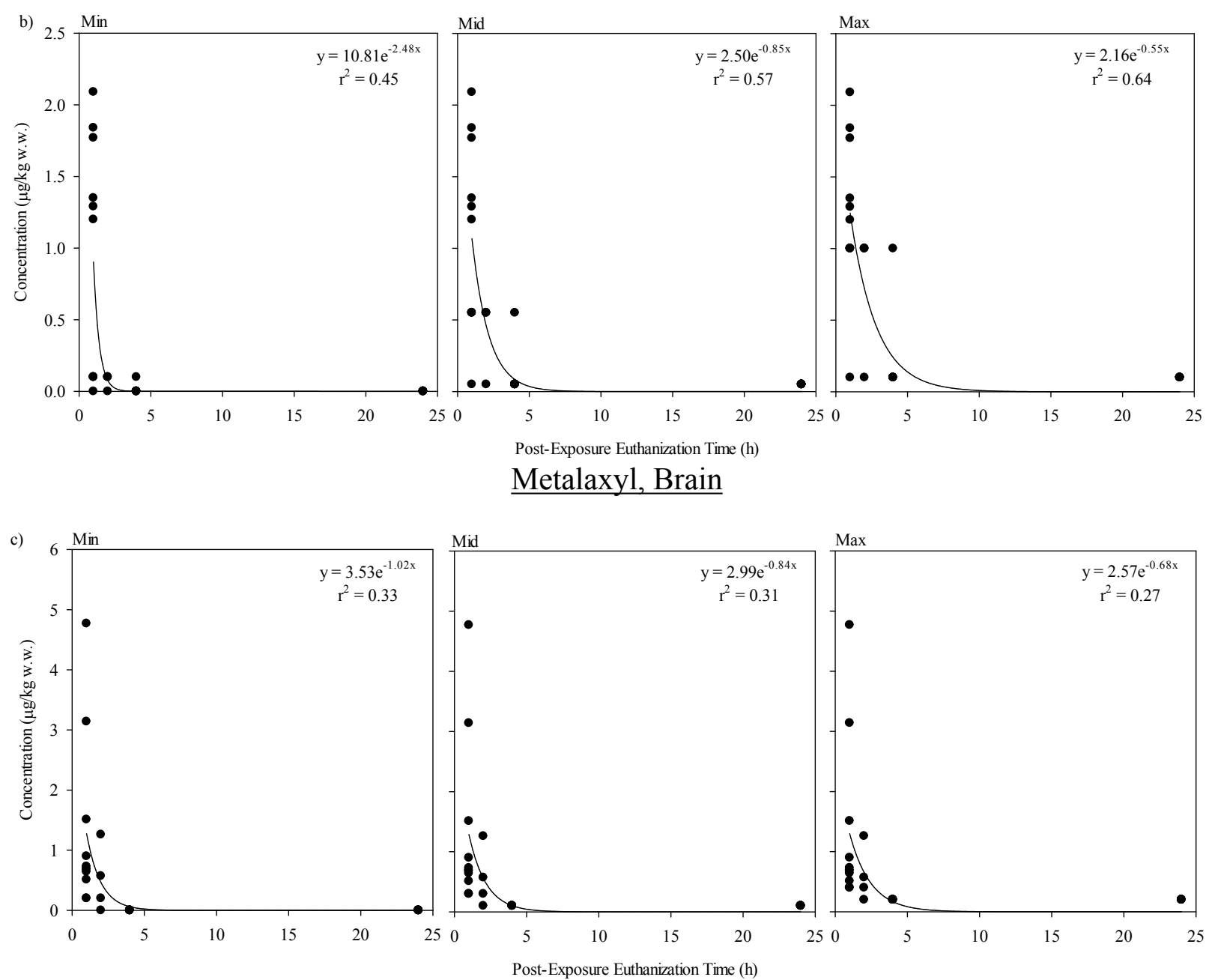


\section{Metalaxyl, Kidney}
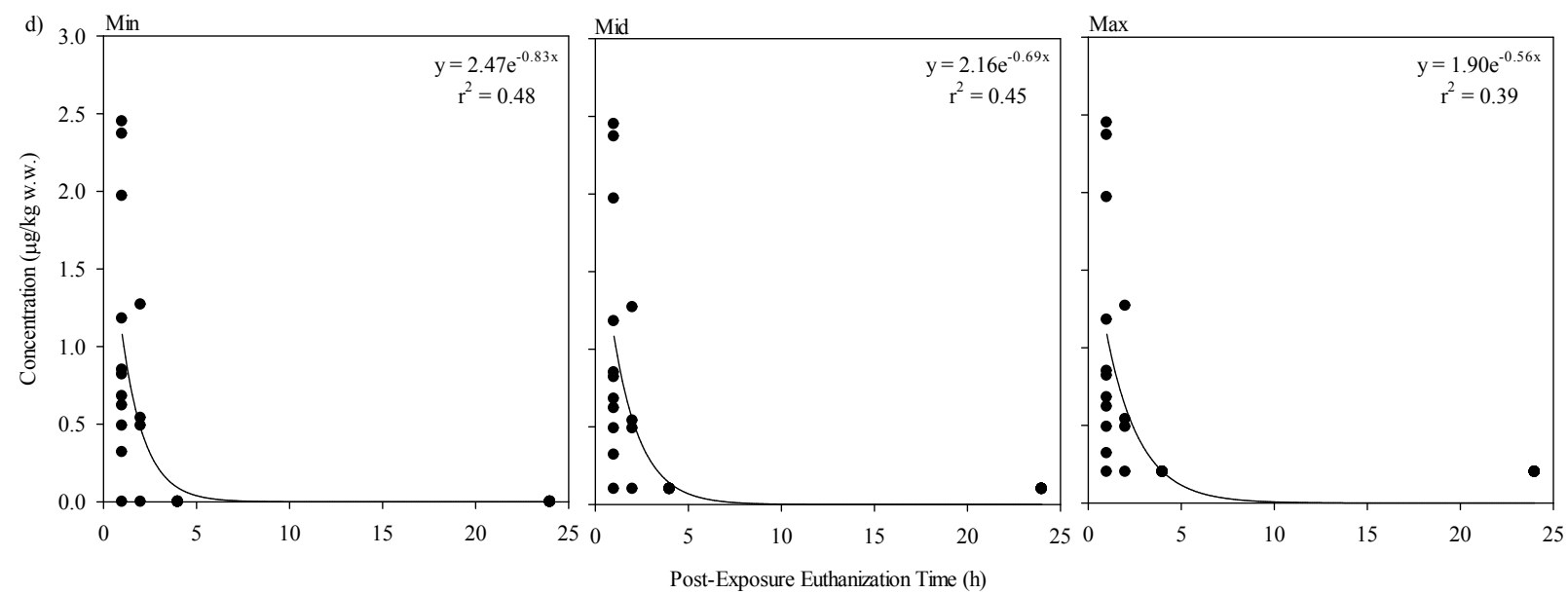

$\underline{\text { Metalaxyl, Muscle }}$
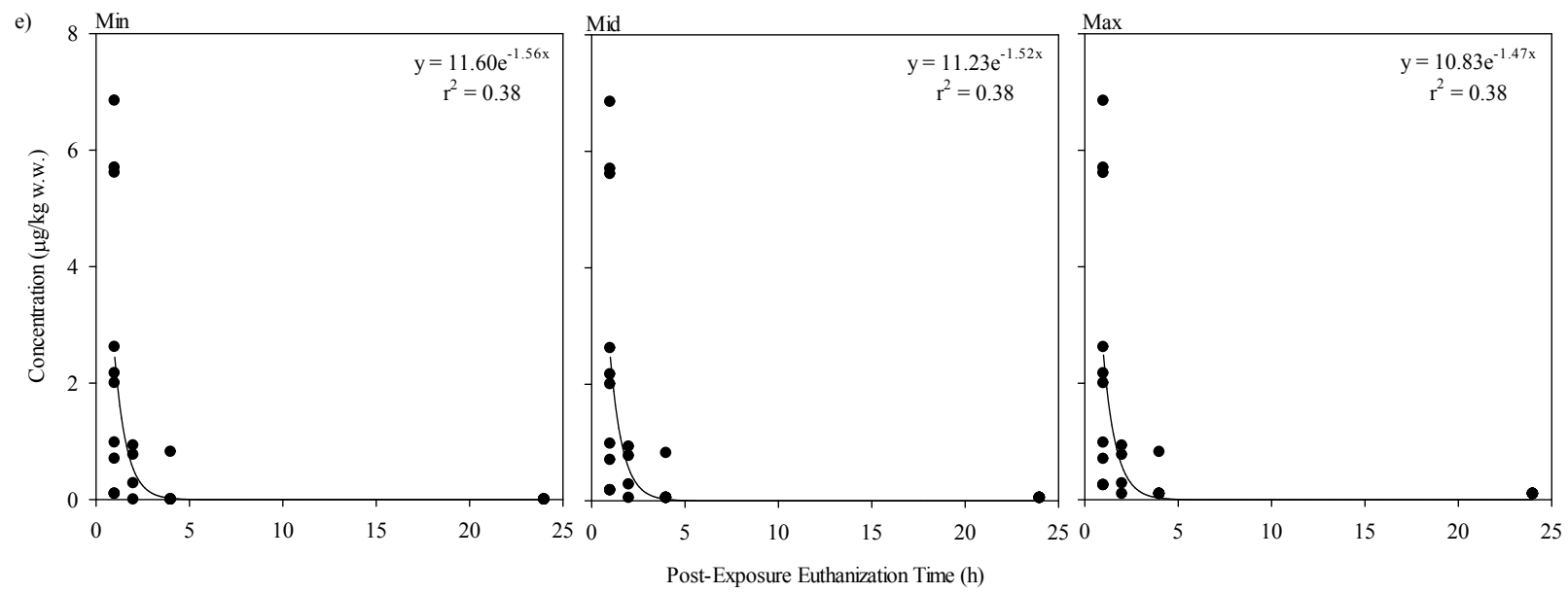

$\underline{\text { Tebuconazole, Liver }}$
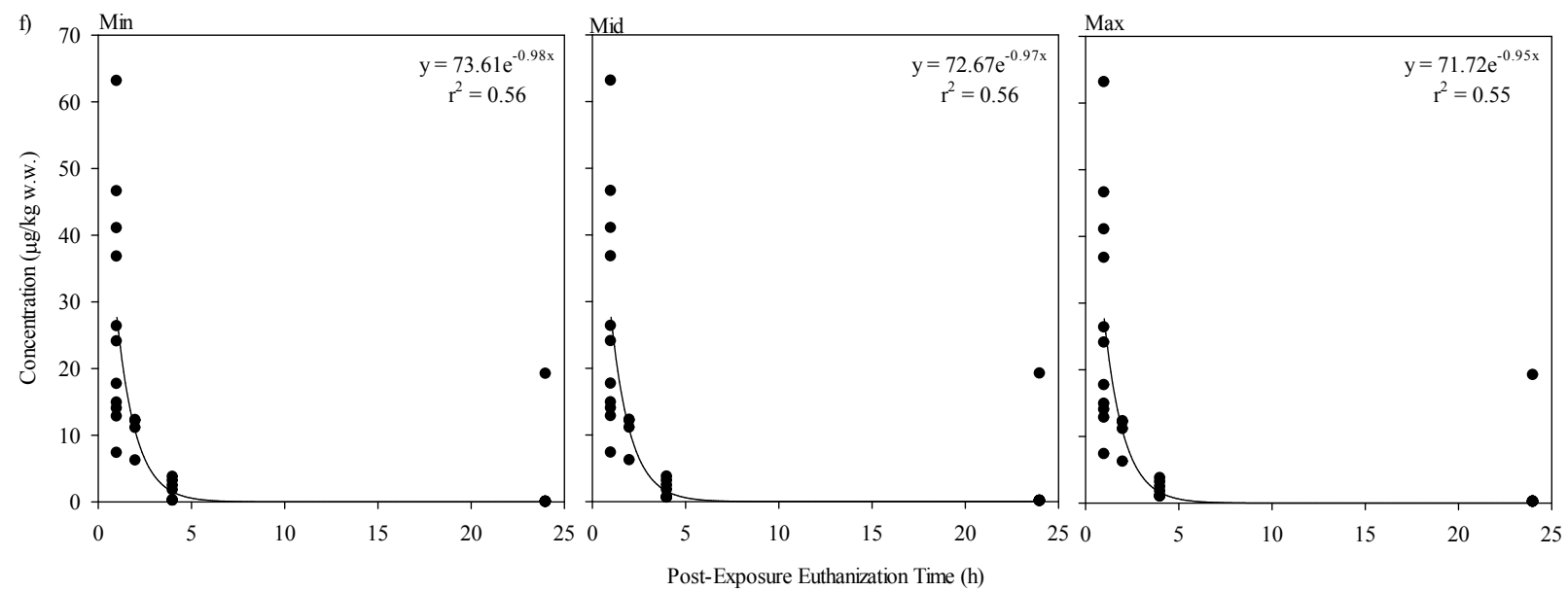


\section{$\underline{\text { Tebuconazole, Brain }}$}
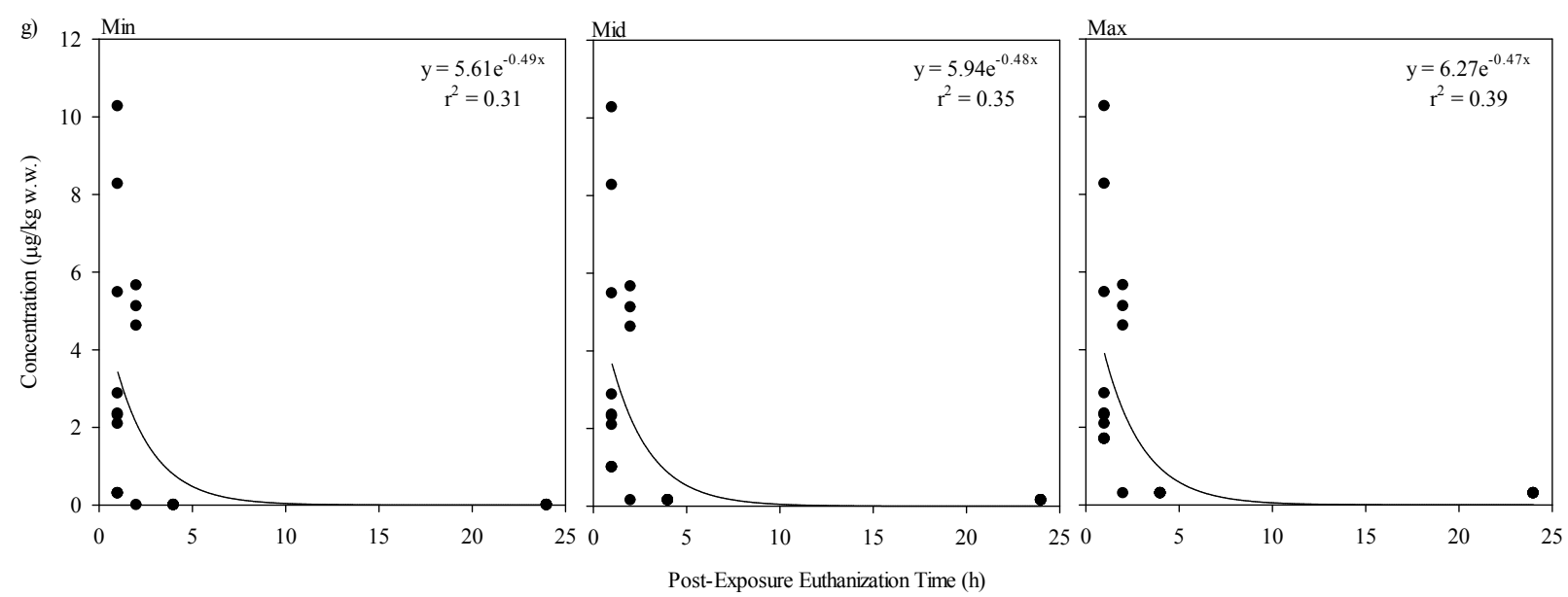

Tebuconazole, Kidney
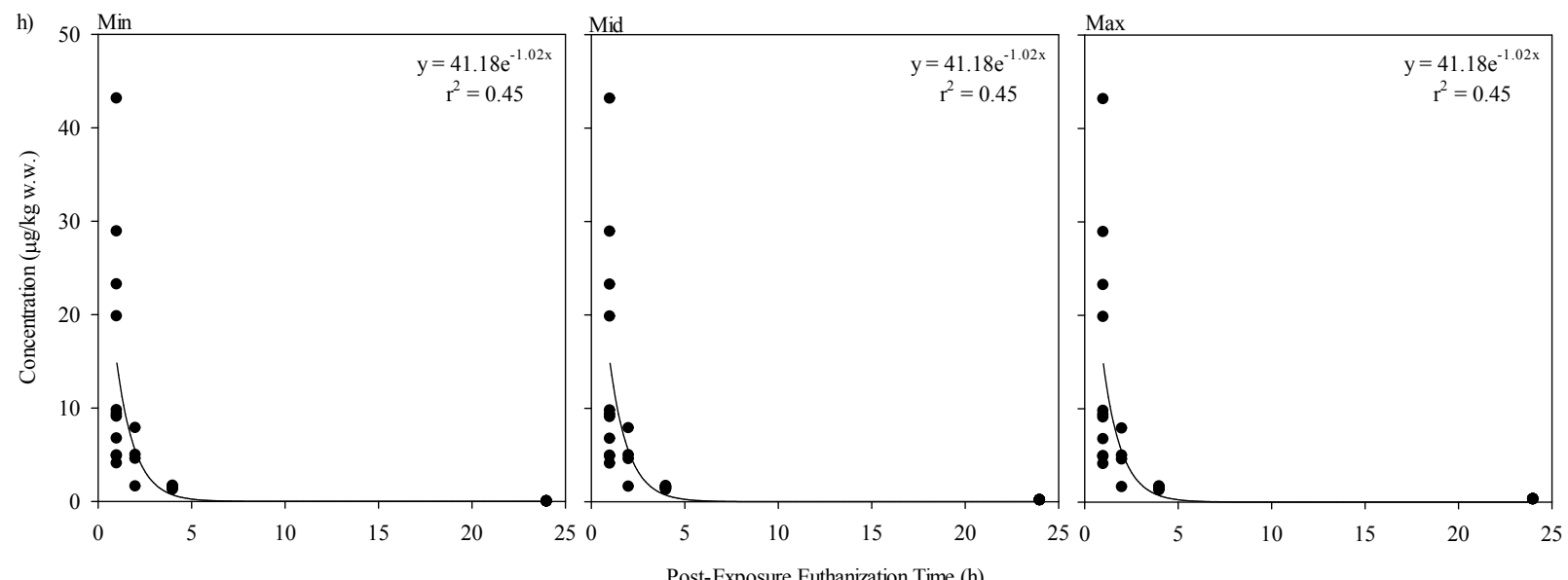

t-Butylhydroxy-tebuconazole, Liver
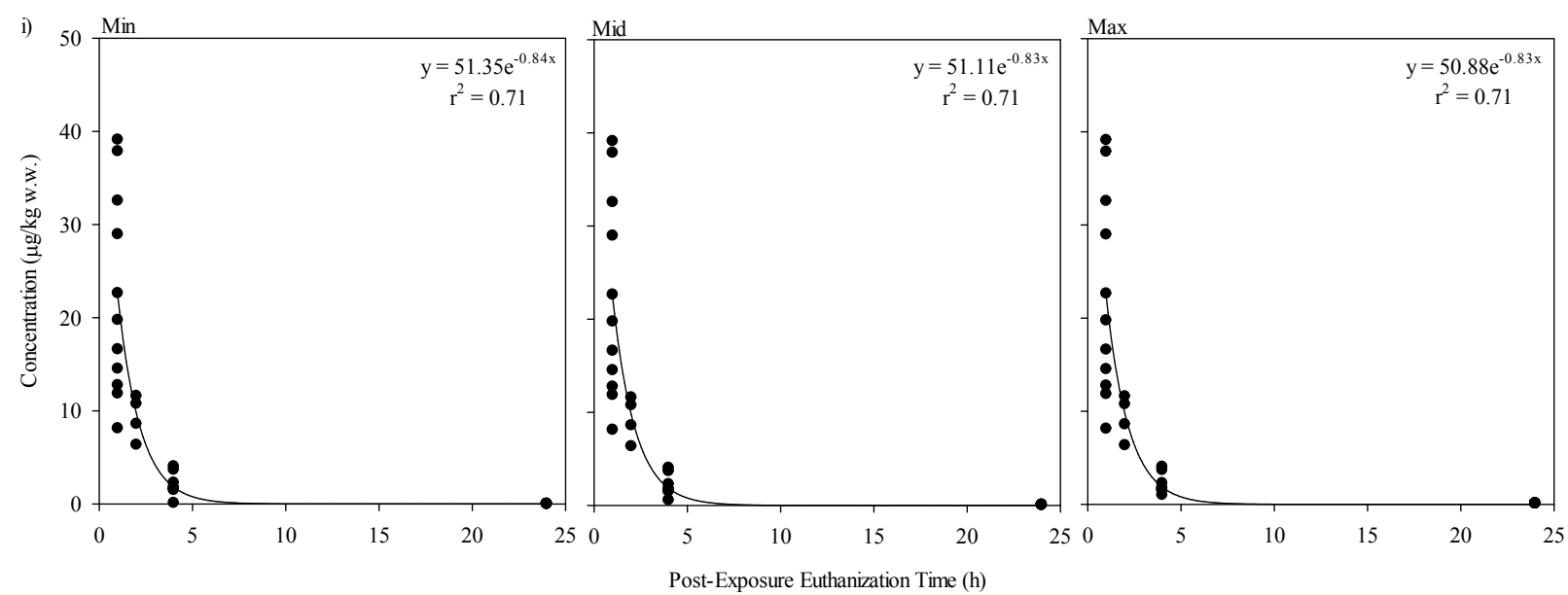


\section{$\underline{t \text {-Butylhydroxy-tebuconazole, Brain }}$}
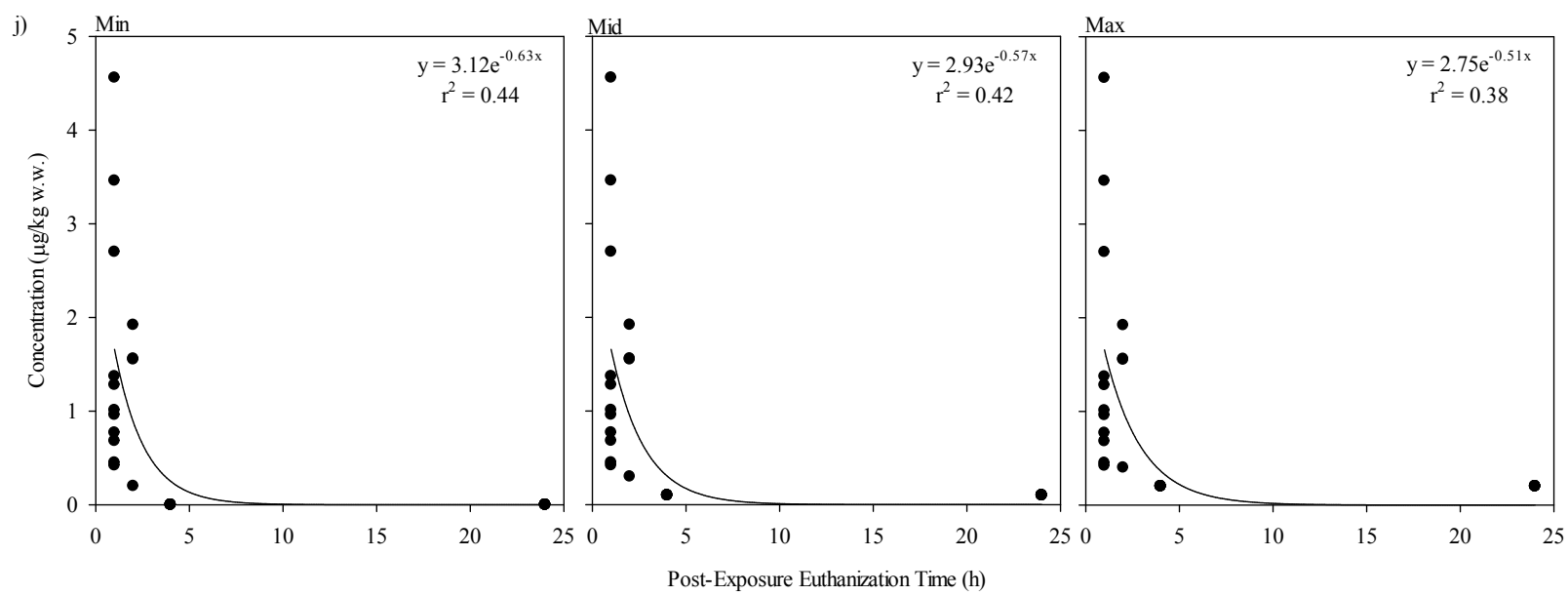

t-Butylhydroxy-tebuconazole, Kidney
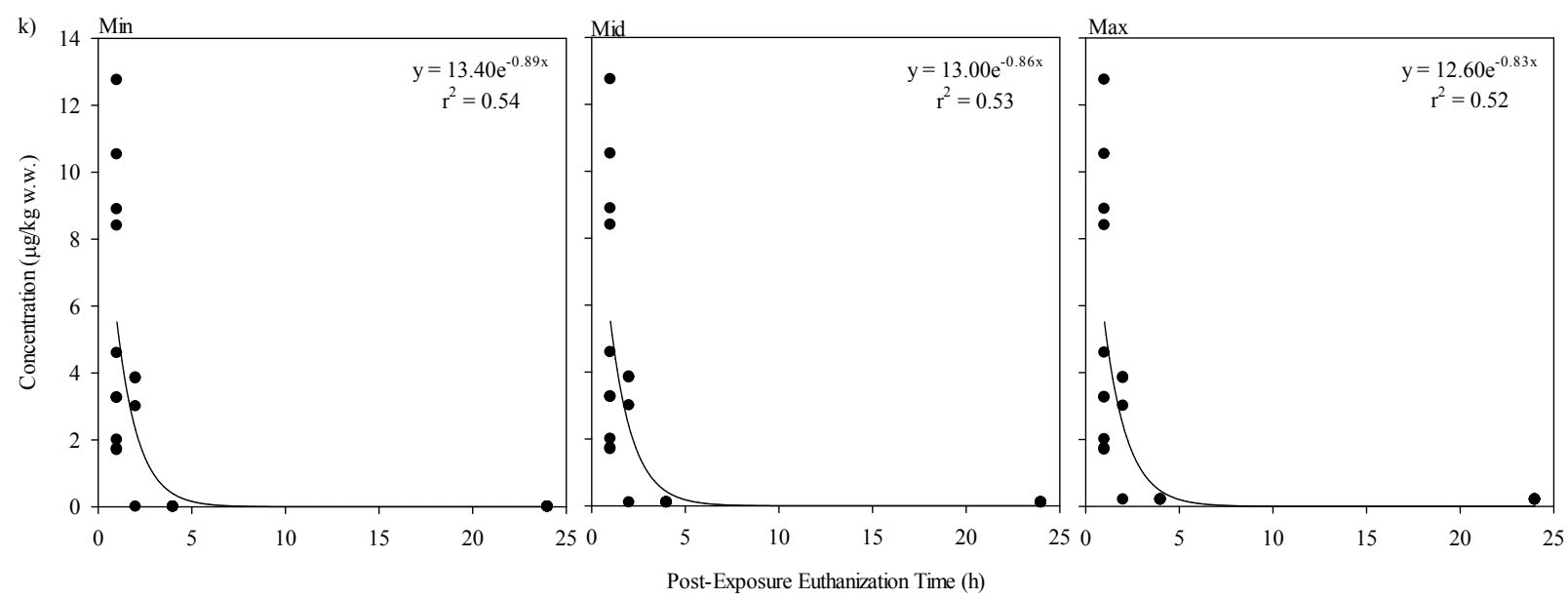

$\underline{t \text {-Butylhydroxy-tebuconazole, Muscle }}$
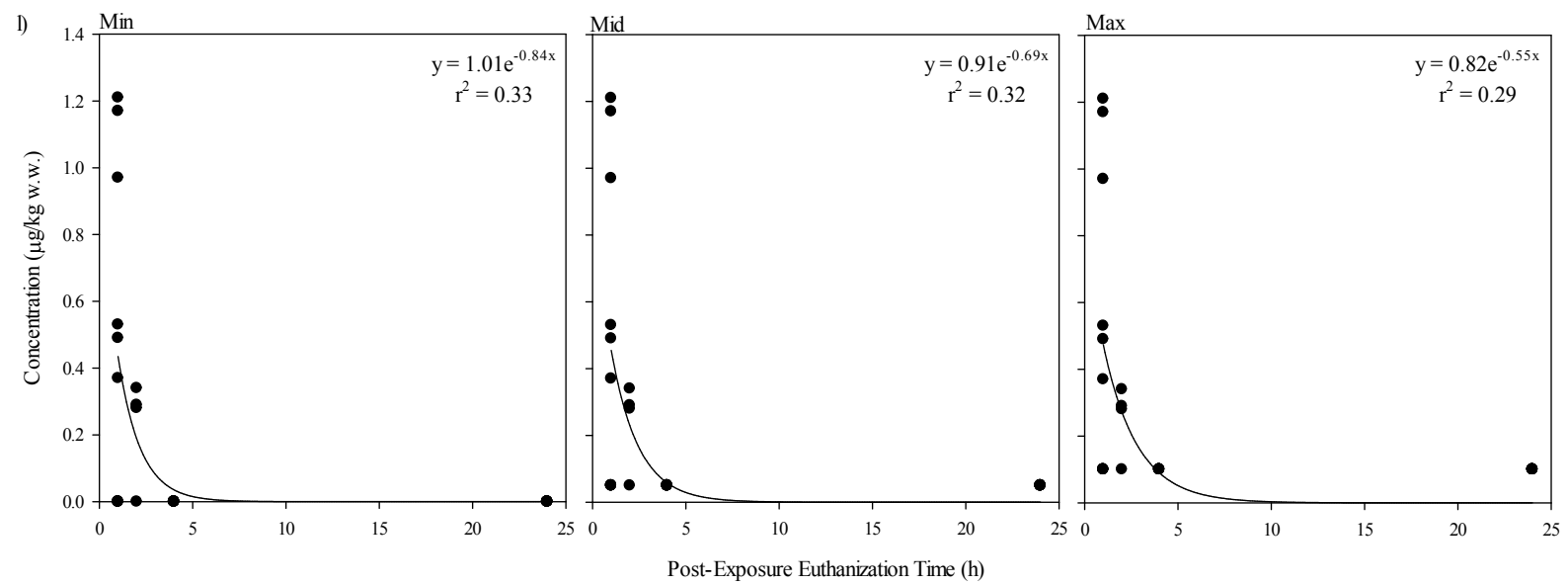

Figure S2: Elimination graphs following the substitution of minimum (min), midpoint (mid), and maximum $(\max )$ values for $<$ LOD or n.d. Graphs represent analyte concentrations detected in high dose samples collected at $1 \mathrm{~h}(\mathrm{n}=11), 2 \mathrm{~h}(\mathrm{n}=4), 4 \mathrm{~h}(\mathrm{n}=8)$, and $24 \mathrm{~h}(\mathrm{n}=8)$ post-exposure. 
Elimination graphs were plotted for the following: metalaxyl in (a) plasma, (b) liver, (c) brain, (d) kidney, and (e) muscle; tebuconazole in (f) liver, (g) brain, and (h) kidney; $t$-butylhydroxytebuconazole in (i) liver, (j) brain, (k) kidney, and (l) muscle. The exponential equation and correlation coefficient are shown for each figure. Rate constants from each equation were used to determine ranges in half-life estimates. 


\begin{tabular}{|c|c|c|c|c|}
\hline \multicolumn{5}{|c|}{ Table S1: Number of Birds Euthanized at Each Time Point } \\
\hline & time point $(h)$ & control & low dose & high dose \\
\hline \multirow{4}{*}{1 day } & 1 & 5 & 5 & 6 \\
\hline & 2 & 1 & 4 & 4 \\
\hline & 4 & 1 & 4 & 4 \\
\hline & 24 & 1 & 4 & 4 \\
\hline \multirow[t]{3}{*}{10 day } & 1 & 5 & 5 & 5 \\
\hline & 4 & 1 & 4 & 4 \\
\hline & 24 & 1 & 4 & 4 \\
\hline Total & & 15 & 30 & 31 \\
\hline
\end{tabular}




\begin{tabular}{|c|c|c|c|c|}
\hline & $\begin{array}{l}\text { retention time } \\
(\mathrm{min})\end{array}$ & $\begin{array}{c}\text { fragmentor voltage } \\
(V)\end{array}$ & $\begin{array}{c}\text { MRM transitions } \\
(\mathrm{m} / \mathrm{z})^{\mathrm{a}}\end{array}$ & $\begin{array}{c}\text { collision energy } \\
(\mathrm{eV})\end{array}$ \\
\hline$d_{3}$-thiamethoxam & 6.3 & 73 & $\begin{array}{l}295 \rightarrow 214 \\
295 \rightarrow 184\end{array}$ & $\begin{array}{c}8 \\
20\end{array}$ \\
\hline$d_{4}$-imidacloprid & 6.9 & 91 & $\begin{array}{l}260.1 \rightarrow 213 \\
260.1 \rightarrow 179\end{array}$ & $\begin{array}{l}12 \\
16 \\
\end{array}$ \\
\hline metalaxyl alanine & 7.3 & 59 & $\begin{array}{l}296.2 \rightarrow 278.1 \\
296.2 \rightarrow 146.1\end{array}$ & $\begin{array}{c}4 \\
12 \\
\end{array}$ \\
\hline metalaxyl & 8.4 & 68 & $\begin{array}{l}280.2 \rightarrow 160.1 \\
280.2 \rightarrow 192.1\end{array}$ & $\begin{array}{l}20 \\
12\end{array}$ \\
\hline t-butylhydroxy-tebuconazole & 8.5 & 121 & $\begin{array}{l}324.2 \rightarrow 70.1 \\
324.2 \rightarrow 125\end{array}$ & $\begin{array}{l}20 \\
50 \\
\end{array}$ \\
\hline fludioxonil & 9.2 & 59 & $\begin{array}{c}266.1 \rightarrow 229 \\
266.1 \rightarrow 157.9\end{array}$ & $\begin{array}{c}4 \\
36\end{array}$ \\
\hline tebuconazole & 9.4 & 92 & $\begin{array}{l}308.2 \rightarrow 70.1 \\
308.2 \rightarrow 125\end{array}$ & $\begin{array}{l}20 \\
40\end{array}$ \\
\hline${ }^{13} C_{3}$-tebuconazole & 9.4 & 112 & $\begin{array}{l}311.2 \rightarrow 70.1 \\
311.2 \rightarrow 125\end{array}$ & $\begin{array}{l}20 \\
36\end{array}$ \\
\hline
\end{tabular}




\begin{tabular}{|c|c|c|c|c|c|c|}
\hline & $\begin{array}{c}\text { plasma } \\
(\mu g / L)\end{array}$ & $\begin{array}{c}\text { liver } \\
(\mu \mathrm{g} / \mathrm{kg})\end{array}$ & $\begin{array}{c}\text { brain } \\
(\mu g / k g)\end{array}$ & $\begin{array}{c}\text { kidney } \\
(\mu g / k g)\end{array}$ & $\begin{array}{l}\text { muscle } \\
(\mu \mathrm{g} / \mathrm{kg})\end{array}$ & $\begin{array}{c}\text { feces } \\
(\mu \mathrm{g} / \mathrm{kg})\end{array}$ \\
\hline metalaxyl & 0.1 & 0.1 & 0.2 & 0.2 & 0.1 & 0.2 \\
\hline metalaxyl alanine & 0.1 & 0.1 & 0.2 & 0.2 & 0.1 & 0.2 \\
\hline tebuconazole & 0.2 & 0.2 & 0.3 & 0.3 & 0.2 & 0.3 \\
\hline t-butylhydroxy-tebuconazole & 0.1 & 0.1 & 0.2 & 0.2 & 0.1 & 0.2 \\
\hline fludioxonil & 1.0 & 1.0 & 1.7 & 1.7 & 1.0 & 1.7 \\
\hline
\end{tabular}




\begin{tabular}{|c|c|c|c|c|c|c|}
\hline & $\begin{array}{c}\text { plasma } \\
(\mu g / L)\end{array}$ & $\begin{array}{c}\text { liver } \\
(\mu \mathrm{kg})\end{array}$ & $\begin{array}{c}\text { brain } \\
(\mu g / k g)\end{array}$ & $\begin{array}{l}\text { kidney } \\
(\mu g / k g)\end{array}$ & $\begin{array}{l}\text { muscle } \\
\text { ( } \mathrm{g} / \mathrm{kg})\end{array}$ & $\begin{array}{c}\text { feces } \\
(\mu \mathrm{g} / \mathrm{kg})\end{array}$ \\
\hline metalaxyl & 0.4 & 1.0 & 0.4 & 0.4 & 0.3 & 0.4 \\
\hline metalaxyl alanine & 0.3 & 1.0 & 0.4 & 1.7 & 0.3 & 1.0 \\
\hline tebuconazole & 1.0 & 1.0 & 1.7 & 1.7 & 1.0 & 1.7 \\
\hline t-butylhydroxy-tebuconazole & 0.3 & 1.0 & 0.4 & 0.4 & 0.3 & 0.4 \\
\hline fludioxonil & 5.0 & 5.0 & 8.3 & 8.3 & 5.0 & 8.3 \\
\hline
\end{tabular}




\begin{tabular}{|c|c|c|c|c|c|c|c|}
\hline sample & $\begin{array}{c}\text { doses } \\
(\#)\end{array}$ & $\begin{array}{c}\text { low plasma } \\
\text { estimate }(\mathrm{mL})\end{array}$ & $\begin{array}{l}\text { high plasma } \\
\text { estimate }(\mathrm{mL})\end{array}$ & $\begin{array}{c}\text { liver } \\
(\mathrm{g})\end{array}$ & $\begin{array}{c}\text { brain } \\
(\mathrm{g})\end{array}$ & $\begin{array}{l}\text { kidney } \\
(\mathrm{g})\end{array}$ & $\begin{array}{c}\text { muscle } \\
(\mathrm{g})\end{array}$ \\
\hline 175, LD1 & 1 & 3.06 & 6.29 & 1.47 & 0.81 & 0.66 & $\mathrm{na}^{\mathrm{a}}$ \\
\hline 128, LD2 & 1 & 2.80 & 5.76 & 1.40 & 0.68 & 0.53 & 28.12 \\
\hline 166, LD3 & 1 & 3.10 & 6.38 & 1.41 & 0.72 & 0.67 & 32.49 \\
\hline 193, LD4 & 1 & 3.20 & 6.59 & 1.71 & 0.70 & 1.40 & 28.19 \\
\hline 153, LD5 & 1 & 2.91 & 5.98 & 1.34 & 0.74 & 0.59 & 26.04 \\
\hline 179, LD6 & 10 & 3.11 & 6.40 & 1.74 & 0.70 & 0.66 & 33.26 \\
\hline 157, LD7 & 10 & 3.33 & 6.85 & 1.68 & 0.83 & 0.59 & 34.51 \\
\hline $162, \mathrm{LD} 8$ & 10 & 3.22 & 6.63 & 1.78 & 0.69 & 0.70 & 35.49 \\
\hline 174, LD9 & 10 & 3.26 & 6.72 & 1.65 & 0.80 & 0.52 & 34.01 \\
\hline 124, LD10 & 10 & 2.77 & 5.70 & 1.89 & 0.70 & 0.74 & 30.83 \\
\hline 133, HD1 & 1 & 2.73 & 5.61 & 1.30 & 0.75 & 0.59 & 28.12 \\
\hline $180, \mathrm{HD} 2$ & 1 & 3.28 & 6.76 & 1.26 & 0.68 & 0.54 & 33.82 \\
\hline $147, \mathrm{HD} 3$ & 1 & 3.09 & 6.36 & 1.56 & 0.74 & 0.65 & 29.19 \\
\hline 141, HD4 & 1 & 3.34 & 6.88 & 1.93 & 0.79 & 0.67 & 31.15 \\
\hline G123, HD5 & 1 & 3.32 & 6.84 & 1.26 & 0.58 & 0.66 & 31.37 \\
\hline 186, HD11 & 1 & 3.21 & 6.60 & 1.75 & 0.78 & 0.63 & 32.35 \\
\hline 125, HD6 & 10 & 2.99 & 6.15 & 1.71 & 0.76 & $\mathrm{na}^{\mathrm{a}}$ & 30.98 \\
\hline 138, HD7 & 10 & 2.98 & 6.13 & 2.05 & 0.68 & 0.71 & 26.77 \\
\hline 191, HD8 & 10 & 3.34 & 6.87 & 1.71 & 0.74 & 0.57 & 32.95 \\
\hline 185, HD9 & 10 & 3.13 & 6.44 & 1.75 & 0.76 & 0.70 & 30.60 \\
\hline 196, HD10 & 10 & 3.45 & 7.11 & 2.03 & 0.77 & 0.69 & 32.13 \\
\hline
\end{tabular}


Table S6: Statistical $p$-values from one-way ANOVA or Kruskal-Wallis one-way ANOVA by ranks examining the effect of dosing days and dosing concentration on concentration levels within Japanese quail plasma and tissues ${ }^{\mathrm{a}}$

\begin{tabular}{|l|c|c|c|c|c|c|}
\hline \multirow{3}{*}{} & \multicolumn{3}{|c|}{ metalaxyl } & \multicolumn{3}{|c|}{ tebuconazole } \\
\cline { 2 - 3 } & low dose $(L D)$ & high dose $(H D)$ & \multirow{2}{*}{$L D$ vs. HD } & low dose $(L D)$ & high dose $(H D)$ & \multirow{2}{*}{ LD vs. HD } \\
\cline { 2 - 3 } & $1 d v s .10 d$ & $1 d v s .10 d$ & & $1 d v s .10 d$ & $1 d v s .10 d$ & \\
\hline plasma & $0.77-0.84$ & 0.93 & 0.20 & 1.00 & 0.66 & 0.34 \\
\hline liver & 0.69 & $0.07-0.20$ & $<0.001$ & $0.60-0.62$ & 0.59 & 0.002 \\
\hline brain & 0.84 & 0.66 & 0.12 & $0.25-0.60$ & 0.33 & 0.29 \\
\hline kidney & 0.84 & $0.64-0.67$ & 0.08 & $0.59-0.60$ & 0.55 & 0.06 \\
\hline muscle & $0.22-0.25$ & $0.52-0.54$ & 0.03 & 0.91 & $0.24-0.29$ & $0.33-0.44$ \\
\hline
\end{tabular}

aIf non-detects (n.d.) or less than limits of detection $(<\mathrm{LOD})$ were present, the Kaplan-Meier method was used to estimate the extremes of the $p$-values 